\title{
Cosmetic wastewater primary treatment by fenton process and final polishing adsorption
}

\author{
Tratamento primário de efluente de indústria cosmética por processo de \\ Fenton e adsorção como polimento final
}

\author{
Lisiée Manzoli I \\ Gonçalves Pereira " \\ Maria Eugênia de Oliveira Ferreira III \\ Núbia Natália de Brito IV \\ Indianara Conceição Ostroski v
}

\begin{abstract}
This work aimed to integrate two wastewater treatment technologies, Fenton process as the primary treatment and adsorption aiming achieve maximum removal efficiency and adequation to the environmental and water legislations. Wastewater from a cosmetics industry plant in the metropolitan area of Goiânia (Brazil) was the object of this research. It was analysed environmental parameters as absorbance, total iron, chemical oxygen demand, $\mathrm{pH}$, total phenols, conductivity, $\mathrm{H}_{2} \mathrm{O} 2$, dissolved oxygen, turbidity, and total solids. They were analyzed in between processes at all stages. The effects of Fe2 + (18.42-257.89 mg L-1) and H2O2 (500-2300 $\mathrm{mg} \mathrm{L-1)} \mathrm{concentrations} \mathrm{and} \mathrm{pH}$ values (3.00-5.50) were studied for the Fenton process treatment. In adsorption, the activated carbon was characterized by infrared spectroscopy, elemental analysis, adsorption and desorption of $\mathrm{N} 2$ and thermogravimetry (TG/DTA). The effect of the contact time $(4 \mathrm{~min}-24 \mathrm{~h})$ and of the temperature variation in the system $20-60{ }^{\circ} \mathrm{C}$ were studied. By integrating the two technologies, a satisfactory removal rate was achieved for the analyzed parameters in the total time of treatment of 82 minutes.
\end{abstract}

Keywords: Cosmetic wastewater; Processes applied; Physical and chemical characterization; Environmental parameters; Technology integration

'Mestranda em Engenharia Química, Instituto de Química, Universidade Federal de Goiás, Goiânia, GO, Brasil lisieepereira@hotmail.com

"Mestra em Engenharia Química, Instituto de Química, Universidade Federal de Goiás, Goiânia, GO, Brasil mariaeof@live.com

I'Doutora em Engenharia Agrícola, Instituto de Química, Universidade Federal de Goiás, Goiânia, GO, Brasil nubiabrito@ufg.br

IVDoutora em Engenharia Química, Instituto de Química, Universidade Federal de Goiás, Goiânia, GO, Brasil indianara_ostroski@ufg.br 


\section{Resumo}

Este trabalho teve como objetivo integrar duas tecnologias de tratamento de águas residuárias, o processo Fenton, como tratamento primário, e adsorção, visando alcançar a máxima eficiência de remoção e adequação às legislações ambientais e de água. O efluente de uma indústria cosmética da região metropolitana de Goiânia (Brasil) foi o objeto desta pesquisa. Foram analisados parâmetros ambientais como absorbância, ferro total, demanda química de oxigênio, $\mathrm{pH}$, fenóis totais, condutividade, $\mathrm{H} 2 \mathrm{O} 2$, oxigênio dissolvido, turbidez e sólidos totais. Eles foram analisados entre processos em todas as etapas. Os efeitos das concentrações de Fe2+ $(18,42-$ $257,89 \mathrm{mg} \mathrm{L}-1)$ e H2O2 (500-2300 mg L-1) e valores de $\mathrm{pH}$ (3.00-5.50) foram estudados para o tratamento do processo de Fenton. $\mathrm{Na}$ adsorção, o carvão ativado foi caracterizado por espectroscopia no infravermelho, análise elementar, adsorção e dessorção de N2 e análise termogravimétrica (TG / DTA). Foram estudados os efeitos do tempo de contato $(4 \mathrm{~min}-24 \mathrm{~h})$ e da variação de temperatura no sistema - 20-60 ${ }^{\circ} \mathrm{C}$. Ao integrar as duas tecnologias, foi alcançada uma taxa de remoção satisfatória para os parâmetros analisados no tempo total de tratamento de 82 minutos.

Palavras-chave: Efluente cosmético; Processos aplicados; Caracterização física e química; Parâmetros ambientais; Integração de tecnologia 


\section{Introduction}

Liquid effluents from the cosmetics industry are usually characterized by high concentrations of organic matter, dyes, metals, surfactants, turbidity, oils and fats, essences, suspended solids and low dissolved oxygen concentration. Many of these substances pose a risk to the environment and human health (DHILLON et al., 2015; OCAÑA-GONZÁLEZ et al., 2015; SU et al., 2015; LEE et al., 2017; BERGER et al., 2018). Studies have shown that conventional treatment methods, such as coagulation/flocculation, are not always efficient to remove or degrade most of the components in the personal care products (PCP) wastewater, and a large amount of these substances is released into aquatic bodies with the municipal wastewater (CINCINELLI et al., 2015). Also, to attempt the stringent regulations concerning industrial wastewaters, new technologies are needed in order to achieve more efficient treatment of cosmetic wastewaters (PUYOL et al., 2011).

Tertiary treatments have been widely explored in the literature, including advanced oxidation processes, like Fenton and adsorption (MAILLER et al., 2016). Combined approaches are generally required and can be used in both treatment and disposal of these substances in the environment (PAWAR; GAWANDE, 2015). Fenton process is an advanced oxidation process, in which hydroxyl radicals are generated from the reaction between hydrogen peroxide with $\mathrm{Fe} 2+/ \mathrm{Fe} 3+$ in a catalytic cycle. Some of its advantages include operational simplicity and high efficiency in the degradation of recalcitrant substances (LYU; ZHOU; WANG, 2016).

This process has been widely used to treat a range of industrial wastewaters (PARIENTE et al., 2014; LYU; ZHOU; WANG, 2016; NORDIN et al., 2017; KIM et al., 2018; ERKAN; TOP; BILGILI, 2019) In this paper, the Fenton process was used as primary treatment for the remediation of the cosmetic effluent whereas adsorption gives the final polishing . Adsorption is a mass transfer process that occurs from a fluid phase to the surface of a solid phase and presents the advantages of low processing cost, simple operation and excellent purification performance (ZHANG et al., 2019). In the solid phase, activated carbons can be used as adsorbents, since they are able to remove various contaminants from wastewater and can be manufactured from a range of raw materials (MA et al., 2015; SUNEETHA; 
SUNDAR; RAVINDHRANATH, 2015; ZHOU et al., 2015; CHENG et al., 2016; BEHVANDI; SAFEKORDI; KHORASHEH, 2017; MELO et al., 2018; WANG, 2018; DE OLIVEIRA FERREIRA et al., 2019).

The main aim of this work was to propose the integration of two treatment technologies using Fenton process and adsorption applied to wastewater from a PCP industry objectifying maximum removal efficiency according to the values of predetermined environmental parameters. Literature concerning the application of these technologies together in cosmetic wastewater treatment for the removal of organic matter is scarce, so it is of great importance to be evaluated.

\section{Materials and methods}

\subsection{Sample origin}

The effluent subject of this study was donated by a cosmetic industry located in the city of Aparecida de Goiânia, (Goiás, Brazil) in August of 2016. The samples were collected after a primary treatment held at the company, which consists of a decantation tank and a flotation system with no use of chemical substances. The company production line includes shampoos, hair conditioners, body and sunscreen lotions.

The sample of approximately 60 liters was homogenized in a polyethylene barrel and stored in cylinders of the same material at $4{ }^{\circ} \mathrm{C}$. The process of sampling, collecting and storing the effluent was carried out according to the Standard Methods for the Examination of Water and Wastewater (SMHWW) procedures (APHA, 1999).

\subsection{Effluent characterization}

The environmental parameters evaluated were $\mathrm{pH}$, absorbance (color), total iron, chemical oxygen demand (COD), total phenols, turbidity, conductivity, dissolved oxygen, residual hydrogen peroxide and total solids.

The initial characterization of the effluent was carried out according to the recommendations of the SMEWW (APHA, 1999), with the exception of hydrogen peroxide and COD, which were adapted. 
The COD determination was performed after the $\mathrm{pH}$ was an increase of $\mathrm{pH}$ to 8.00 and the sample was then heated to $80^{\circ} \mathrm{C}$ for 40 minutes to remove residual $\mathrm{H} 2 \mathrm{O} 2$. The sample remained at rest for 2 hours (ambient temperature) to sediment residual iron that interferes with the result, as well as termination the Fenton's reaction (SHETTY; VERMA, 2015)

Residual hydrogen peroxide was determined according to Oliveira et al. (2001). The analysis is based on the reaction between hydrogen peroxide and vanadate ion (VO3-) in acid medium, which leads to to the formation of peroxovanadium ion ( $\mathrm{VO} 23+)$. This cation is of reddish color and strongly absorbs electromagnetic radiation at $\lambda=446 \mathrm{~nm}$.

The dosage of chemical reagents used for the Fenton's reaction assays ranged from 18.42-257.89 mg L-1 for $\mathrm{Fe} 2+$, 500-2300 mg L-1 for hydrogen peroxide concentration (hydrogen peroxide was used as the oxidizing agent in concentrations of $10 \%$ in an advanced oxidation process, standardized by permanganometric titration) and a variation in $\mathrm{pH}$ values from 3.00 to 5.50 .

Initially in 8 jars containing $1 \mathrm{~L}$ of effluent each, the $\mathrm{pH}$ was adjusted, after that, a solution of ferrous sulfate heptahydrate (as a source of $\mathrm{Fe} 2+$ ) was added to the jars at concentrations outlined by studies. Immediately after this step, the jars containing the previously prepared samples were attached to the Jar Test equipment and the samples were shaken for 6 minutes and 30 seconds: in the first 20 seconds at $300 \mathrm{rpm}$ and the remaining time at $30 \mathrm{rpm}$, as previously programmed into the equipment. At 20 seconds under constant agitation, hydrogen peroxide solution was added simultaneously to each test at different concentrations. At the end, all the samples were allowed to stand for sedimentation at room temperature for 60 minutes.

The parameters of treatment time and rotation, as well as the range of initial concentrations of chemical reagents were used for the treatment technology (Fenton's reagent). It were also based on the values of the parameters used in Pereira and Brito (2018) Morais and Brito (2015), Ma and Xia (2009), and in the wastewater treatment station of Goiânia-GO.

A summary of how the technologies were used is shown in Figure 1. It is based in the crude cosmetic effluent involving a primary treatment through Fenton process and subsequently the treatment with adsorption to provide final polishing. 
Figure 1 - Treatment summary applicated on the cosmetic effluent

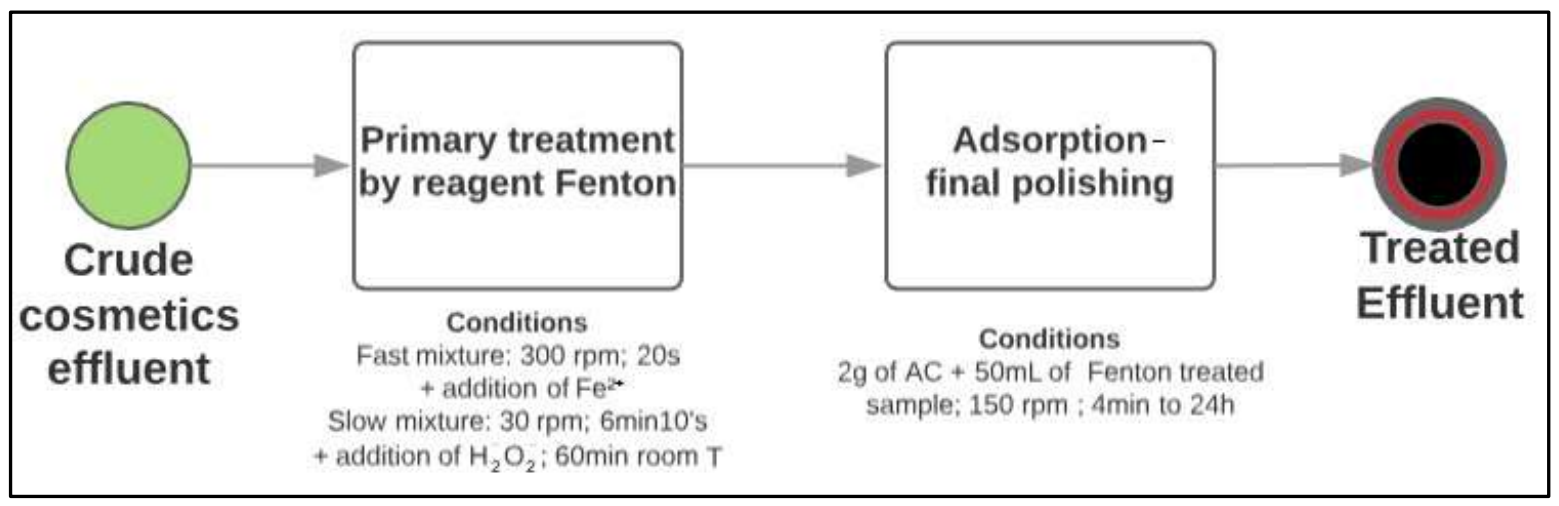

\subsection{Adsorption analysis}

After treatment with Fenton, the effluent was subjected to batch adsorption using commercial activated carbon as an adsorbent (FBC LTDA). The activated carbon was subjected to chemical treatment with $\mathrm{NaOH}$ in order to increase the adsorption efficiency of compounds that are present in the effluent. Since the effluent in this study has a strong acidic character $(\mathrm{pH} 2.33)$ and as it remains acidic after the Fenton process, the objective was to make the surface of the activated carbon more alkaline in order to increase the chemical interactions between the adsorbate and the surface of the adsorbent.

The method consisted of adding $10 \mathrm{~g}$ of activated carbon and $50 \mathrm{~mL}$ of $\mathrm{NaOH} 2 \mathrm{~mol}$ $\mathrm{L}-1$ in an Erlenmeyer flask $(125 \mathrm{~mL})$ and placing it in a shaker at $120 \mathrm{rpm}$ and $25^{\circ} \mathrm{C}$ for 24 hours. The charcoal sample was then separated from the $\mathrm{NaOH}$ solution by vacuum pump filtration and washed with $2 \mathrm{~L}$ of distilled water to remove the excess of alkaline solution. Finally, the sample was dried in an oven at $130^{\circ} \mathrm{C}$ for $24 \mathrm{~h}$, according to the methodology described by Chiang et al. (2002).

Then, the activated carbon was submitted to the analysis point of zero charge, elemental analysis, adsorption and desorption of N2, infrared spectroscopy (FTIR), Boehm titration, thermogravimetric analysis and differential thermal analysis. 


\subsection{Kinetic studies}

Sixteen samples were prepared in the kinetic test, where $2 \mathrm{~g}$ of activated carbon was added to $50 \mathrm{~mL}$ of post-Fenton treated effluent in a $125 \mathrm{~mL}$ Erlenmeyer flask. The samples were removed from the shaker $(150 \mathrm{rpm})$ at pre-established times (ranging from $4 \mathrm{~min}$ to 24 h). At each withdrawal, the liquid sample was immediately separated from the adsorbent by filtration using the vacuum pump. Afterwards, COD and turbidity measurements were performed.

The effect of temperature was studied following the same method used to determine the equilibrium time. Each test was performed separately for temperatures of $20^{\circ} \mathrm{C}, 30^{\circ} \mathrm{C}$, $40^{\circ} \mathrm{C}, 50^{\circ} \mathrm{C}$ and $60^{\circ} \mathrm{C}$.

\section{Results and discussion}

\subsection{Effluent initial characterization}

The effluent was initially characterized by the following environmental parameters: chemical oxygen demand (COD), hydrogenionic potential $(\mathrm{pH})$, turbidity, conductivity, dissolved oxygen (DO), total phenols, total iron, hydrogen peroxide, total solids and absorbance.

As it can be observed in Table 1, there are various physico-chemical parameters of the industry wastewater giving values beyond the emission limit range. The main concern regarding industrial effluent is the high COD value which may reflect a large amount of nonbiodegradable organic matter.

Table 1 - Effluent initial characterization and legal limits for discharge

\begin{tabular}{l|c}
\hline \multicolumn{1}{c|}{ Environmental quality parameter } & Effluent sample \\
\hline COD (mg L-1) & 24524 \\
\hline $\mathrm{pH}$ & 2.33 \\
\hline Turbidity (NTU) & 4520 \\
\hline
\end{tabular}




\begin{tabular}{|c|c|c|}
\hline \multicolumn{2}{|c|}{ Conductivity (mS cm-1) } & 2.05 \\
\hline \multicolumn{2}{|c|}{ Dissolved oxygen (mg L-1) } & 3.71 \\
\hline \multicolumn{2}{|c|}{ Total phenols (mg L-1) } & 1550.78 \\
\hline \multicolumn{2}{|c|}{ Total iron (mg L-1) } & 0.00 \\
\hline \multicolumn{2}{|c|}{ Hydrogen Peroxide (mg L-1) } & 16.48 \\
\hline \multirow{3}{*}{ Solids (mg L-1) } & Total & 15196 \\
\hline & Fixed Total & 265 \\
\hline & Volatile Total & 14931 \\
\hline \multirow{2}{*}{ Absorbance } & $200 \mathrm{~nm}$ & 1.580 \\
\hline & 400nm & 0.433 \\
\hline
\end{tabular}

The absorbance of each wavelength may represent the presence of the different substances that constitute the effluent. In this work, the wavelengths used as reference were 200 and $400 \mathrm{~nm}$. The high absorbance measured at $200 \mathrm{~nm}$ represents the presence of several groups that are strongly absorbed at this wavelength, such as: $C=C, C=C, C=O$, $\mathrm{COOH}, \mathrm{C}=\mathrm{N}$ and NO2. Chromophore groups such as components of pigments and dyes used in shampoos, conditioners and moisturizing lotions (GÜRSES et al., 2016) are absorbed at $400 \mathrm{~nm}$.

\subsection{Fenton process treatment - Preliminary experiments}

It is important to stress that the practical efficiency of the Fenton process strongly depends on various factors such as temperature, $\mathrm{pH}, \mathrm{H} 2 \mathrm{O} 2$, and catalyst concentrations, which control the regeneration capacity of $\mathrm{Fe} 2+$ from $\mathrm{Fe} 3+$ produced during the process and the rate of oxidation of organics by generated $\cdot O H$ (OTURAN; AARON, 2014).

Therefore, preliminary tests were conducted since it had the highest removal efficiency for COD (24.61\%). Because of its estimated representation of organic matter and the difficulty of its removal, COD is the most important parameter. The results for turbidity was $29.09 \%$ removal. In this experiment, $1000.00 \mathrm{mg} \mathrm{L}-1$ of $\mathrm{H} 2 \mathrm{O} 2$ and $25.80 \mathrm{mg} \mathrm{L}-1$ of total soluble iron were used at an initial pH of 4.00 . 
It is important to highlight that in the Fenton process, ferrous ions are oxidized to ferric ions and ferric hydroxo complexes, which accounts for the coagulation capability of Fenton's reagent. The suspended solids are then captured and precipitated out. Since the $\mathrm{HO}$ - radical attacks organic compounds, it leads to the chemical decomposition of these compounds. Therefore, the Fenton process can perform both oxidation and coagulation functions in the treatment (MA; XIA, 2009; RODRIGUES et al., 2017).

From the data produced by preliminary tests, the $\mathrm{H} 2 \mathrm{O} 2$, total soluble iron concentration, and $\mathrm{pH}$ values were varied to determine the best conditions for the Fenton's reaction, starting with a concentration of total soluble iron (18.42 e $257.89 \mathrm{mg} \mathrm{L}-1$ ) maintaining $\mathrm{H} 2 \mathrm{O} 2$ at $1000.00 \mathrm{mg} \mathrm{L}-1$ and $\mathrm{pH}$ at 4.00 .

\subsubsection{Effect of ferrous dosage}

In Figure 2 it was clear that the values of COD and turbidity decrease in the range of 18.42 to $184.21 \mathrm{mg} \mathrm{L}-1$, when the maximum removal reaches $48.37 \%$ and $60.62 \%$, respectively. Therefore, the most appropriate concentration of $\mathrm{Fe} 2+$ ions to the system is $184.21 \mathrm{mg} \mathrm{L}-1$. Below this value, the concentration of $\mathrm{Fe} 2+$ ions is insufficient to catalyze the Fenton reaction. From $184.21 \mathrm{mg} \mathrm{L}-1$ of $\mathrm{Fe} 2+$ ions, the higher the addition of ferrous ions to the system, the lower the efficiency of the process.

Meanwhile, it was observed that large amounts of small flocs were suspended in the supernatant and were difficult to settle down. Hence, the increasing dosage of ferrous sulfate significantly improved the turbidity and COD removal in the range of $117.89-184.21 \mathrm{mg} \mathrm{L}-$ 1.

Figure 2 - Effect of Fe2 + concentration on the turbidity and COD removal $(\mathrm{pH}=4.00$;

$$
\mathrm{H} 2 \mathrm{O} 2 \text { concentration }=1000 \mathrm{mg} \mathrm{L}-1)
$$

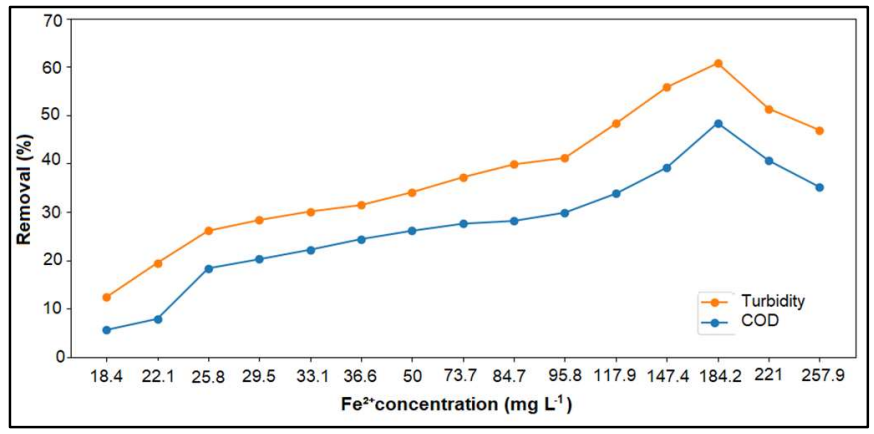


According to Andrade et al. (2015), Wang et al. (2016) and Ma \& Xia (2009), Equation 1 and 2 describes the interaction of ferrous ions acting as radicals scavenger $(\cdot \mathrm{OH} / \mathrm{HO} 2 \cdot)$, when there is high iron concentration in the system, producing $\mathrm{Fe} 3+$ and $\mathrm{OH}$ - ions:

$$
\begin{aligned}
& \mathrm{Fe} 2++\cdot \mathrm{OH} \rightarrow \mathrm{Fe} 3++\mathrm{HO}-\mathrm{k}=2.8 \times 108 \mathrm{~L} \mathrm{~mol}-1 \mathrm{~s}-1(1) \\
& \mathrm{Fe} 2++\mathrm{HO} 2 \cdot \rightarrow \mathrm{Fe} 3++\mathrm{HO} 2-=1.3 \times 106 \mathrm{~L} \mathrm{~mol}-1 \mathrm{~s}-1(2)
\end{aligned}
$$

When the reaction kinetics between the Fenton main equation (Eq. 3) and Equation (1 and 2) are compared, it is possible to observe that the latter is favored by the excess $\mathrm{Fe} 2+$ ions in the system, where there is no generation of hydroxyl radicals (GANZENKO et al., 2018).

$$
\mathrm{Fe} 2++\mathrm{H} 2 \mathrm{O} 2+\mathrm{H}+\rightarrow \mathrm{Fe} 3++\cdot \mathrm{OH}+\mathrm{H} 2 \mathrm{OK}=40-80 \mathrm{~L} \mathrm{~mol}-1 \mathrm{~s}-1(3)
$$

The $\mathrm{Fe} 3+$ ions in solution contribute to the formation of the hydroperoxyl radical through the decomposition of hydrogen peroxide (Eq. 4). The hydroperoxyl radical, $\mathrm{HO} \bullet$, $(E 0=1.42 \mathrm{~V})$ has a lower redox potential than the hydroxyl radical $(E 0=2.80 \mathrm{~V})$, which can reduce the efficiency of the Fenton process.

$$
\mathrm{Fe} 3++\mathrm{H} 2 \mathrm{O} 2 \rightarrow \mathrm{Fe} 2++\mathrm{HO} 2 \cdot+\mathrm{H}+\mathrm{k}=0.001-0.01 \mathrm{~L} \mathrm{~mol}-1 \mathrm{~s}-1(4)
$$

The Fenton-like reaction (Eq 4) is a two step process. At first, $\mathrm{Fe} 3+$ and $\mathrm{H} 2 \mathrm{O} 2$ form a complex (Eq 4a -b) which decomposes into Fe2+ and HO2 • (Eq 4c-d), whereas Fe2+speciation remains constant at $\mathrm{pH}$ values relevant for Fenton chemistry Fe3+ speciation changes in this $\mathrm{pH}$ range. $\mathrm{At} \mathrm{pH} \leq 2.2 \mathrm{Fe} 3+$ is the dominant Fe3+-species and changes into $\mathrm{Fe}(\mathrm{OH}) 2+$ in the $\mathrm{pH}$ range 2.2-3.5. At $\mathrm{pH} \geq 3.5 \mathrm{Fe}(\mathrm{OH}) 2+$ becomes prevalent. These species show differences in the complex formation equilibrium of about 1 order of magnitude, whereas in case of the decay of the complex it cannot be differentiated kinetically between $\mathrm{Fe}(\mathrm{OOH}) 2+$ and $\mathrm{Fe}(\mathrm{OH})(\mathrm{OOH})+($ WIEGAND et al., 2017). 


$$
\begin{aligned}
& \mathrm{Fe} 3++\mathrm{H} 2 \mathrm{O} 2 \leftrightarrows \mathrm{Fe}(\mathrm{OOH}) 2++\mathrm{H}+\mathrm{K}=3.1 \times 10-3(4 \mathrm{a}) \\
& \mathrm{FeOH} 2++\mathrm{H} 2 \mathrm{O} 2 \leftrightarrows \mathrm{Fe}(\mathrm{OH})(\mathrm{OOH})++\mathrm{H}+\mathrm{K}=2 \times 10-4(4 \mathrm{~b}) \\
& \mathrm{Fe}(\mathrm{OOH}) 2+\rightarrow \mathrm{Fe} 2++\mathrm{HO} 2 \cdot \mathrm{k}=2.7 \times 10-3 \mathrm{~s}-1(4 \mathrm{c}) \\
& \mathrm{Fe}(\mathrm{OH})(\mathrm{OOH})+\rightarrow \mathrm{FeOH}++\mathrm{HO} 2 \cdot \mathrm{k}=2.7 \times 10-3 \mathrm{~s}-1(4 \mathrm{~d})
\end{aligned}
$$

The excessive increase of $\mathrm{Fe} 2+$ ions in the system, also interfere in the turbidity removal, since $\mathrm{Fe} 2+$ ions undergo $\mathrm{Fe} 3+$ oxidation In this case, there is formation of iron hydroxides (Eq. 5-7), which may increase the turbidity of the system (MORAIS; BRITO, 2015).

$$
\begin{aligned}
& \mathrm{Fe} 3++6 \mathrm{H} 2 \mathrm{O} \leftrightarrows[\mathrm{Fe}(\mathrm{H} 2 \mathrm{O}) 6] 3+(5) \\
& {[\mathrm{Fe}(\mathrm{H} 2 \mathrm{O}) 6] 3++\mathrm{H} 2 \mathrm{O} \leftrightarrows[\mathrm{Fe}(\mathrm{H} 2 \mathrm{O}) 5(\mathrm{OH})] 2++\mathrm{H} 3 \mathrm{O}+(6)} \\
& {[\mathrm{Fe}(\mathrm{H} 2 \mathrm{O}) 5(\mathrm{OH})] 2++\mathrm{H} 2 \mathrm{O} \leftrightarrows[\mathrm{Fe}(\mathrm{H} 2 \mathrm{O}) 4(\mathrm{OH}) 2]++\mathrm{H} 3 \mathrm{O}+(7)}
\end{aligned}
$$

The COD and turbidity values are most efficiently removed at $184.21 \mathrm{mg} \mathrm{L}-1$ when the removal reaches $48.37 \%$ and $60.62 \%$, respectively. The results found in this study are in agreement with other works in the literature (BAUTISTA et al., 2014; NAUMCZYK et al., 2014), which obtained similar results. Bautista et al. (2014), which studied the treatment of cosmetic wastewaters by Fenton $(\mathrm{Fe} 2+/ \mathrm{H} 2 \mathrm{O} 2)$ and Fenton-like $(\mathrm{Fe} 3+/ \mathrm{H} 2 \mathrm{O} 2)$ oxidation, observed COD reductions of around 55\% after $2 \mathrm{~h}$ reaction time. Naumczyk et al. (2014) obtained for optimal doses of $\mathrm{H} 2 \mathrm{O} 2 / \mathrm{Fe}$ (II) equal to 1500/190 mg L-1 and after $60 \mathrm{~min}$ of the process, a COD removal of $75.1 \%$.

\subsubsection{Effect of $\mathrm{H} 2 \mathrm{O} 2$ dosage}

The $\mathrm{H} 2 \mathrm{O} 2$ concentration plays an important role in the efficiency of the process. If hydrogen peroxide undergoes catalytic decomposition, it generates free radicals (Equations 3 and 4); on the other hand, it can act as hydroxyl radical interceptor ( $2.80 \mathrm{eV}$ ) by generating a hydroperoxyl radical, which lowers the redox potential (1.42 eV) as shown in Equation 8 (DE ANDRADE; RAFAEL DUFRAYER; DE BRITO, 2018). 
In order to evaluate the influence of the hydrogen peroxide in the Fenton process, ten tests were performed ranging from 500 to $1300 \mathrm{mg} \mathrm{L}-1$ of $\mathrm{H} 2 \mathrm{O} 2$, at constant $\mathrm{pH}$ (4.00) and Fe2+ concentration (184.21 mg L-1). The results are presented in the graph of Figure 3.

Figure 3 - Effect of $\mathrm{H} 2 \mathrm{O} 2$ concentration on the turbidity and COD removal $(\mathrm{pH}=4.00$; $\mathrm{Fe} 2+$ concentration $=184.21 \mathrm{mg} \mathrm{L}-1)$.

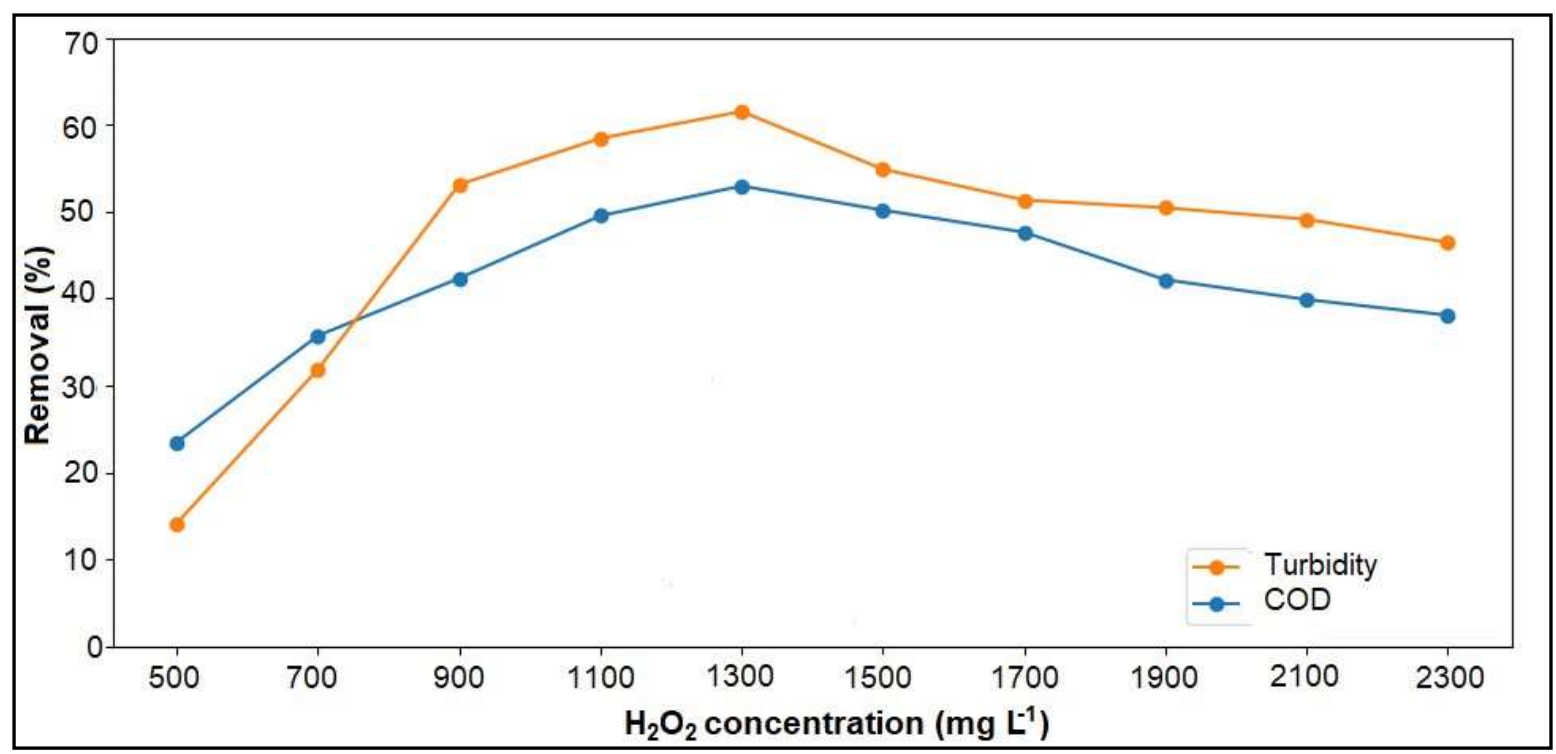

In the $\mathrm{H} 2 \mathrm{O} 2$ concentration range between 500 and $1300 \mathrm{mg} \mathrm{L}-1$, it is possible to observe an increasing removal in the values of turbidity and COD parameters, which reach the peaks of $61.50 \%$ and $52.94 \%$, respectively. Thereafter, the removal efficiency in the system is reduced. Thus, the most adequate hydrogen peroxide concentration in the system is $1300 \mathrm{mg} \mathrm{L}-1$.

According to the main reaction of Fenton, the concentration of $\mathrm{H} 2 \mathrm{O} 2$ is determinant for the formation of hydroxyl radicals. When this reagent is scarce in the system, insufficient hydroxyl radicals are generated to degrade all the organic matter in the effluent. The reduction of the efficiency from the $1300 \mathrm{mg} \mathrm{L}-1$ point is justified by the existence of intermediate reactions that occur concomitantly to the main reaction in the Fenton process. 
The production of the hydroxyl radical decreases with the influence of hydroxyl radical sequestration in the presence of excess $\mathrm{H} 2 \mathrm{O} 2$ (Eq. 8), leading to hydroperoxyl radical formation (less reactive), and by radicals recombination (Eq. 9-10), which regenerate the hydrogen peroxide in the system (GUO et al., 2010; ELMOLLA; CHAUDHURI, 2011). It is also important to highlight the auto-scavenging reactions, deactivating radicals species with reduction potential and forming oxygen and water (Eq. 11).

$$
\begin{aligned}
& \mathrm{H} 2 \mathrm{O} 2+\cdot \mathrm{OH} \rightarrow \mathrm{HO} 2 \cdot+\mathrm{H} 2 \mathrm{Ok}=1.7-4.5 \times 107 \mathrm{~L} \mathrm{~mol}-1 \mathrm{~s}-1(8) \\
& \cdot \mathrm{OH}+\cdot \mathrm{OH} \rightarrow \mathrm{H} 2 \mathrm{O} 2 \mathrm{k}=5-8 \times 109 \mathrm{~L} \mathrm{~mol}-1 \mathrm{~s}-1(9) \\
& 2 \mathrm{HO} 2 \cdot \rightarrow \mathrm{O} 2+\mathrm{H} 2 \mathrm{O} 2 \mathrm{k}=1 \times 106 \mathrm{~L} \mathrm{~mol}-1 \mathrm{~s}-1(10) \\
& \mathrm{HO} 2 \cdot+\cdot \mathrm{OH} \rightarrow \mathrm{O} 2+\mathrm{H} 2 \mathrm{Ok}=1.0 .1010 \mathrm{~L} \mathrm{~mol}-1 \mathrm{~s}-1(11)
\end{aligned}
$$

According to Ragasson (2013), to achieve greater efficiency of Fenton's reagent, the typical ratio of $[\mathrm{Fe}+2]$ and [H2O2] must be in the range of 1:5 to 1:10. Nevertheless, it is known this ratio depends on the nature of the effluent and its organic load (ANDRADE et al., 2015; OLIVEIRA et al., 2015; FONTMORIN; SILLANPÄÄ, 2017). The relation between $\mathrm{Fe} 2+$ ions and hydrogen peroxide presented after Fenton process for cosmetic effluent, was 1: 7.06 .

\subsubsection{Effect of $\mathrm{pH}$}

It has been observed that the $\mathrm{pH}$ is a highly important factor for the effective Fenton treatment. The influence of the $\mathrm{pH}$ was verified maintaining fixed concentrations of ferrous ions and hydrogen peroxide at $184.21 \mathrm{mg} \mathrm{L}-1$ and $1300 \mathrm{mg} \mathrm{L}-1$, respectively (Figure 4).

The highest removal of $\mathrm{COD}$ and turbidity occurred at $\mathrm{pH} 3.5$, with maximum reduction of $57.91 \%$ and $68.58 \%$, respectively. The $\mathrm{Fe} 3+$ ions generated in the Fenton reaction can form complexes of ferric hydroxide due to limited solubility of $\mathrm{Fe} 3+$ at $\mathrm{pH}>4$ (solubility product Ksp of $\mathrm{Fe}(\mathrm{OH}) 3=2.79 \times 10-39)$ (WIEGAND et al., 2017). 
At $\mathrm{pH}$ above 4, amorphous precipitate formation occurs through the polymerization of these complexes, which reduces the efficiency of the process by the decrease of ) $\mathrm{Fe} 2+/ \mathrm{Fe} 3+$ availability in the Fenton process (Eq. 12-13) (TANG, 2003; MA; XIA, 2009).

$2[\mathrm{Fe}(\mathrm{H} 2 \mathrm{O}) 5 \mathrm{OH}] 2+\leftrightarrows[\mathrm{Fe} 2(\mathrm{H} 2 \mathrm{O}) 8(\mathrm{OH}) 2] 4++2 \mathrm{H} 2 \mathrm{O}(12)$

$[\mathrm{Fe} 2(\mathrm{H} 2 \mathrm{O}) 8(\mathrm{OH}) 2] 4++\mathrm{H} 2 \mathrm{O} \leftrightarrows[\mathrm{Fe} 2(\mathrm{H} 2 \mathrm{O}) 7(\mathrm{OH}) 3] 3++\mathrm{H} 3 \mathrm{O}+(13)$

Figure 4 - Effect of pH value on the turbidity and COD removal $(\mathrm{H} 2 \mathrm{O} 2$ concentration $=1300 \mathrm{mg} . \mathrm{L}-1 ; \mathrm{Fe} 2+$ concentration $=184.21 \mathrm{mg} \mathrm{L}-1)$

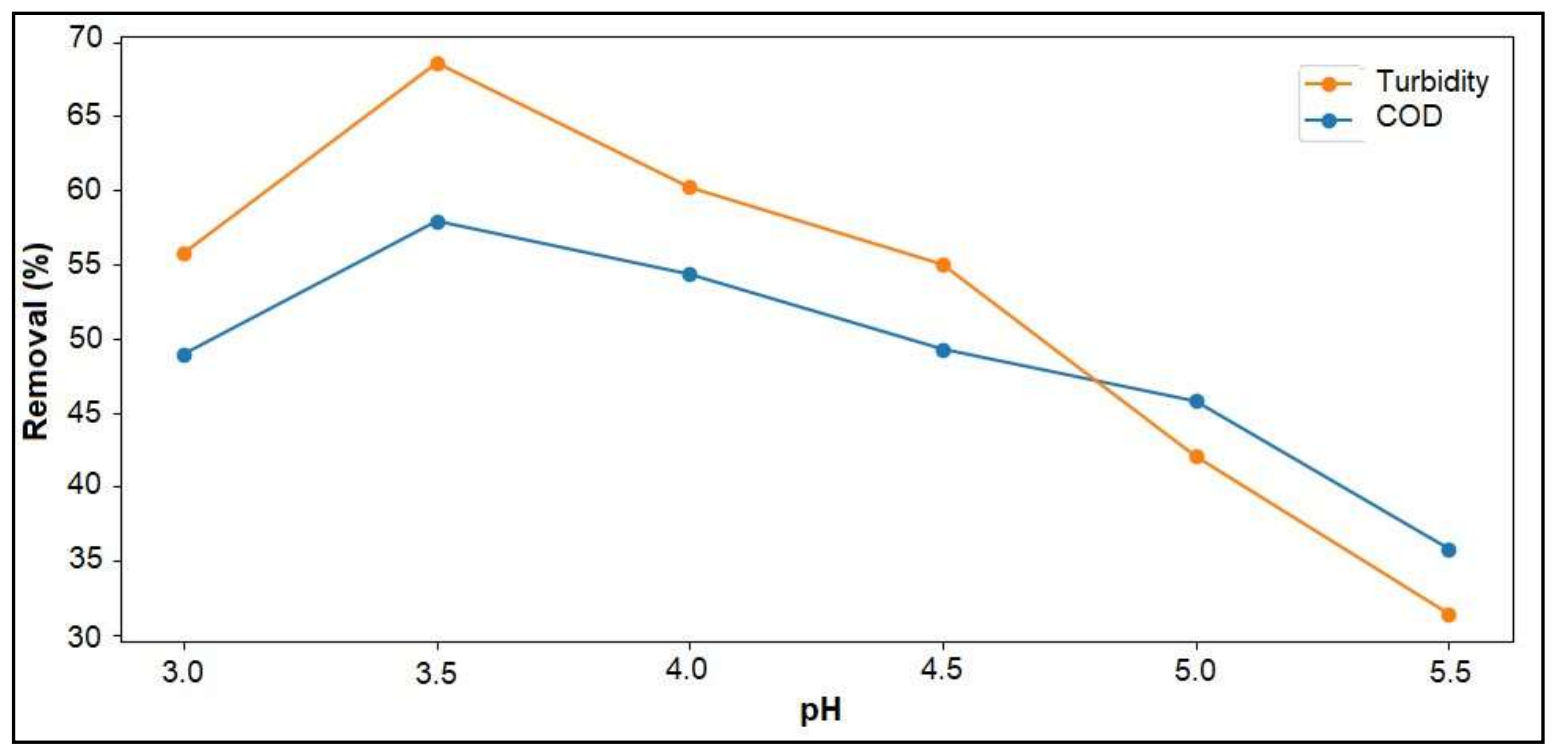

The COD removal started to decrease at $\mathrm{pH} 4.5$ due to the increasing rate of autodecomposition, deactivation of $\mathrm{H} 2 \mathrm{O} 2$ and the increased scavenging effect of $\mathrm{HO}$ • resulting in a decreased oxidation potential of $\mathrm{HO} \cdot$ acording to Equations 14-17 (BAUTISTA et al., 2014; PEREIRA; BRITO, 2018).

$$
\begin{aligned}
& 2 \mathrm{H} 2 \mathrm{O} 2 \rightarrow \mathrm{O} 2+2 \mathrm{H} 2 \mathrm{O}(14) \\
& \mathrm{H} 2 \mathrm{O} 2 \leftrightarrows \mathrm{H}++\mathrm{HO}_{2}-(15) \\
& . \mathrm{OH}+\mathrm{CO} 32-\rightarrow \mathrm{OH}-+\mathrm{CO}^{-}-(16) \\
& . \mathrm{OH}+\mathrm{HCO} 3-\rightarrow \mathrm{H} 2 \mathrm{O}+\mathrm{CO} 3-.(17)
\end{aligned}
$$


At excessively low $\mathrm{pH}$, the hydroperoxonium ion [H3O2]+ is also formed from the reaction between $\mathrm{H}+$ and hydrogen peroxide, which consumes $\mathrm{H} 2 \mathrm{O} 2$ from the system (Eq. 18) (YARGIC; OZBAY, 2016). Finally, although under $\mathrm{pH} 2.5$ there are still soluble iron species, the high concentration of $\mathrm{H}+$ reacts with the hydroxyl radicals to form water molecules (Eq. 19) (VAISHNAVE et al., 2014). This explains the low removal efficiency in the $\mathrm{pH}$ range below 3.5 .

$$
\begin{aligned}
& \mathrm{H} 2 \mathrm{O} 2+\mathrm{H}+\leftrightarrows[\mathrm{H} 3 \mathrm{O} 2]+(18) \\
& \mathrm{H}++\cdot \mathrm{OH}+\mathrm{e}-\rightarrow \mathrm{H} 2 \mathrm{Ok}=7 \times 109 \mathrm{~L} \mathrm{~mol}-1 \mathrm{~s}-1(19)
\end{aligned}
$$

In addition, destabilization is a primary driving force in flocculation and the suspension stability is related with the $\mathrm{pH}$ according to the zeta potential-pH relationship. Destabilization is easily achieved and particles are prone to aggregation with the decrease of $\mathrm{pH}(<4)$. This procedure could also be beneficial to improve the efficiency of Fenton process (dual functions of oxidation and coagulation in the treatment process) (MA; XIA, 2009; PEREIRA; BRITO, 2018).

In the present work, the maximum removal of COD (57.91\%) and turbidity (68.58\%) in 66 minutes is consistent with the results found in the literature for the same treatment. Advanced oxidation processes may have higher removal percentages when applied in conjunction with other treatments, as in Morais \& Brito (2015).

\subsection{Adsorption}

\subsubsection{Adsorbent Characterization}

\subsubsection{Point of zero charge and polarity change of the adsorbent}

The point of zero charge (PZC) was determined by the "11 point experiment" (PARK; REGALBUTO, 1995). Approximately $50 \mathrm{mg}$ of the samples were mixed with $20 \mathrm{~mL}$ of $0.1 \mathrm{~mol} \mathrm{~L}-1 \mathrm{NaCl}$ solution with $\mathrm{pH}$ between 2 and 12 (varying by pH intervals of 1.0) in 100 $\mathrm{mL}$ Erlenmeyers. The $\mathrm{pH}$ of the solutions was adjusted using $0.1 \mathrm{~mol} \mathrm{~L}-1$ solutions of either $\mathrm{HCl}$ or $\mathrm{NaOH}$. After shaking for $24 \mathrm{~h}$, the final $\mathrm{pH}$ of the mixtures was determined using a 
benchtop $\mathrm{pH}$ meter. The $\mathrm{PZC}$ corresponds to the range in which the final $\mathrm{pH}$ remains constant regardless of the initial $\mathrm{pH}$, in which the surface behaves as a buffer.

For the activated carbon without chemical treatment (AC) the pHPZC was 6.8, whilst for the chemically treated with $\mathrm{NaOH}$ charcoal $(\mathrm{ACNaOH})$, the pHPZC was 7.8. Thus, both the $A C$ and $A C N a O H$ coals presented an amphoteric behavior, with pHPZC close to neutrality, although the first one showed somewhat acidic surface and the second one, alkaline.

According to Chiang et al. (2002), during the alkaline treatment, a hydroxylation reaction can occur, in which new functional groups formed from the chemical washing with $\mathrm{NaOH}$ occupy the pores of the active sites. Similar results were obtained by Li et al.(2002) and Mazarji et al. (2017).

The polarity change resulted in an increase of $2.41 \%$ for the COD parameter and $2.40 \%$ for the turbidity. The increase in COD removal and turbidity, even if discrete, is likely to be related to the increase of the activated charcoal surface in the functional groups due to the modification of the superficial $\mathrm{pH}$, which caused a greater affinity with the aqueous substances (BOHLI; OUEDERNI, 2016). However, the values of increased removal of environmental parameters were not very significant when evaluated in terms of costbenefit. Therefore, the procedure is considered unfeasible in this case and as a consequence, only the $\mathrm{AC}$ continued to be used in the adsorption treatment.

\subsubsection{Elemental analysis}

Elemental analysis ( $\mathrm{CHN}-\mathrm{O})$ was performed on the activated carbon both before and after the adsorption tests using an elemental analyzer (FLASH 2000 CHNS/O Analyzers, Thermo Scientific). It was verified that the activated carbon after adsorption suffered a superficial increase in its contents of carbon ( $80.9 \%$ to $81.5 \%)$ and hydrogen ( $0.9 \%$ to 1.3$)$, which indicates functionalization of organic matter in the activated charcoal pores during the adsorption process. The discrete increase in the percentage of carbon may be due to the presence of oxygen in the analysis vessel, which may imply a not so inert atmosphere. The increase of hydrogen indicates functionalization of hydrogenated groups. The small reduction in the percentage of nitrogen (from $0.7 \%$ to $0.6 \%$ ) can be explained by the 
increase in temperature associated with the use of an activating agent, which causes the elimination of volatile substances (RIO et al., 2005).

\subsubsection{Adsorption and desorption of $\mathrm{N} 2$}

Specific surface areas, pore diameter, total volume of pores and micropores volume of the activated carbons were performed at Central Analytics Multiuser Lab of IQ UFG, by nitrogen adsorption-desorption isotherm measurements at 77 K, using an ASAP 2020 Plus Micromeritics instrument. Total pore volume per single point total pore volume was determined at $\mathrm{p} / \mathrm{p} 0=0.95$ The micropore volume was determined by the t-plot method (LIPPENS; DE BOER, 1965). Pore distribution was determined by the BJH method (BARRETT; JOYNER; HALENDA, 1951).

The adsorption and desorption isotherms of $\mathrm{N} 2$ for the $\mathrm{AC}$ are shown in Figure 5 . It is possible to verify that they are type I isotherms. In this case, most of the surface is made up of micropores, presenting dimensions less than $20 \AA$. The pore saturation occurs at a relatively low pressure as a consequence of their diameter. The observed hysteresis is type $\mathrm{H} 4$, which suggests the presence of crack-like pores.

The activated charcoal presented $832.7 \mathrm{~m} 2 \mathrm{~g}-1$ of the surface area, $659.4 \mathrm{~m} 2 \mathrm{~g}-1$ of micropore area and $0.4092 \mathrm{~cm} 3 \mathrm{~g}-1$ of total pore volume. Thus, the area of micropores represents approximately $79 \%$ of the total area of pores in the AC. The analysis of the pore diameter of the activated charcoal corroborates with pore distribution isotherm, in which a higher occurrence of pores below $20 \AA$ is observed. The higher occurrence of micropores is a characteristic of physically activated coals, with gases and vapors (MANOCHA; MOVALIYA, 2007). In the case of AC, the activation occurred with water vapor.

(Continue...) 
Figure 5 - Adsorption and desorption of N2 isotherms and pore size distribution in the $A C$

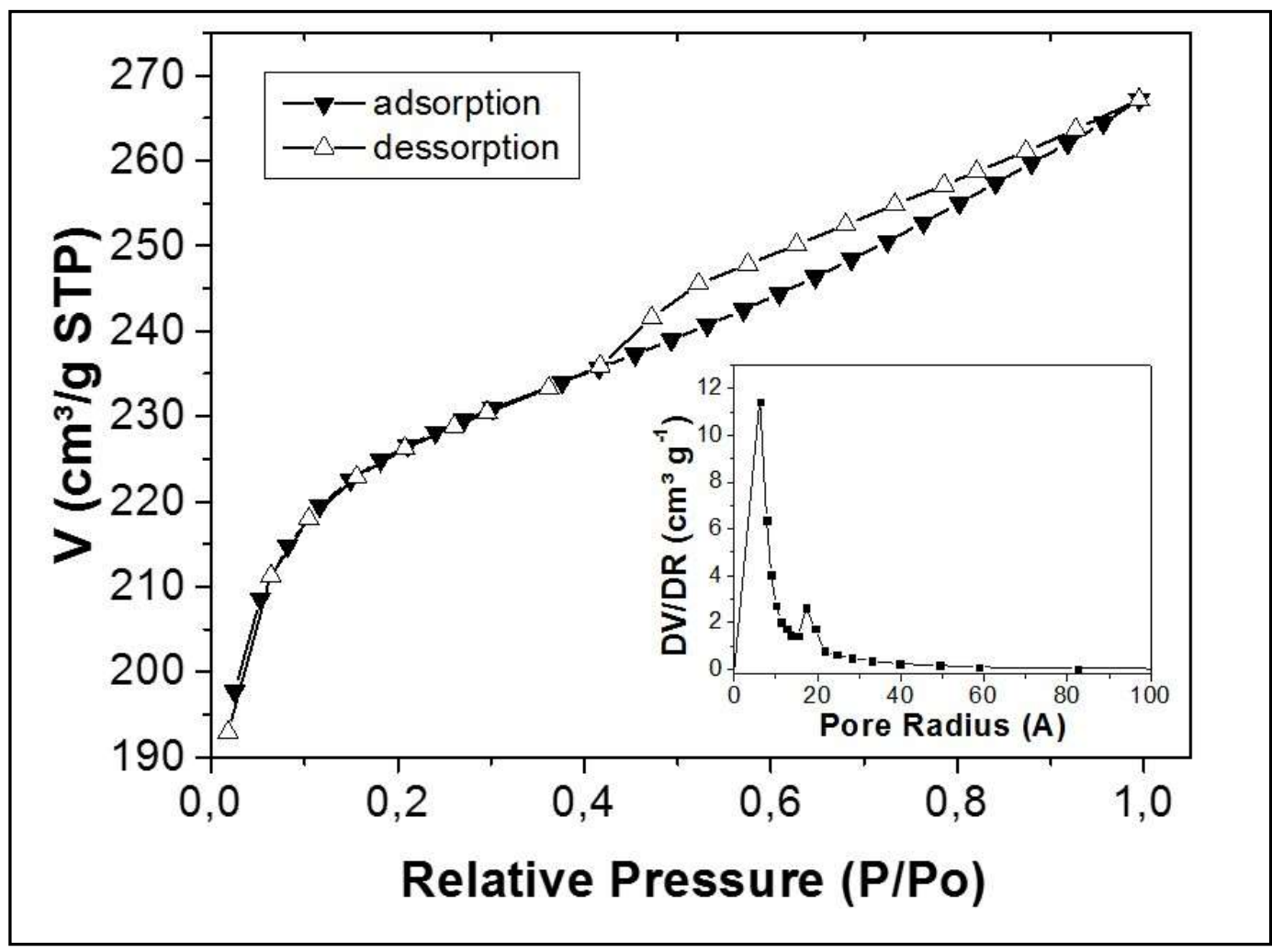

\subsubsection{Fourier-transform infrared spectroscopy (FTIR)}

FTIR spectra were acquired using Bruker Vertex 70 equipment. Samples were prepared in $\mathrm{KBr}$ pellet at a concentration of $0.12 \%$. The spectra were obtained in the spectral range of $400-4000 \mathrm{~cm}-1$, with increments of $4 \mathrm{~cm}-1$, each spectrum being the result of the average of 128 measurements. The infrared spectra for the activated charcoal before and after the adsorption are shown in Figure 6.

The $1564 \mathrm{~cm}-1$ peak is related to the asymmetric stretching for groups such as $\mathrm{N}=\mathrm{O}$, $\mathrm{C}=\mathrm{C}, \mathrm{C}=\mathrm{N}, \mathrm{C}=\mathrm{O}$ and $\mathrm{N}-\mathrm{H}$. In the $1112 \mathrm{~cm}-1$ range, $\mathrm{C}-\mathrm{O}$ stretching occurs with adjacent stretches of $\mathrm{C}-\mathrm{C}, \mathrm{C}-\mathrm{N}$, and $\mathrm{C}-\mathrm{H}$, indicating the possible presence of saturated, unsaturated and aromatic esters, amines and alcohols. As the mass of the atom attached to the carbon increases, the frequency of vibration decreases. In the $500 \mathrm{~cm}-1$ range $(485 \mathrm{~cm}-$ 1 in the graph), there are $C-I$ stretch and the presence of haloalkanes, which can be used in cosmetics (DAFFALA; MUKHTAR; SHAHARUN, 2010; MOOSA; RIDHA; KADHIM, 2016) as organic solvents. 
Figure 6 - FTIR spectrum for AC, before and after the adsorption process

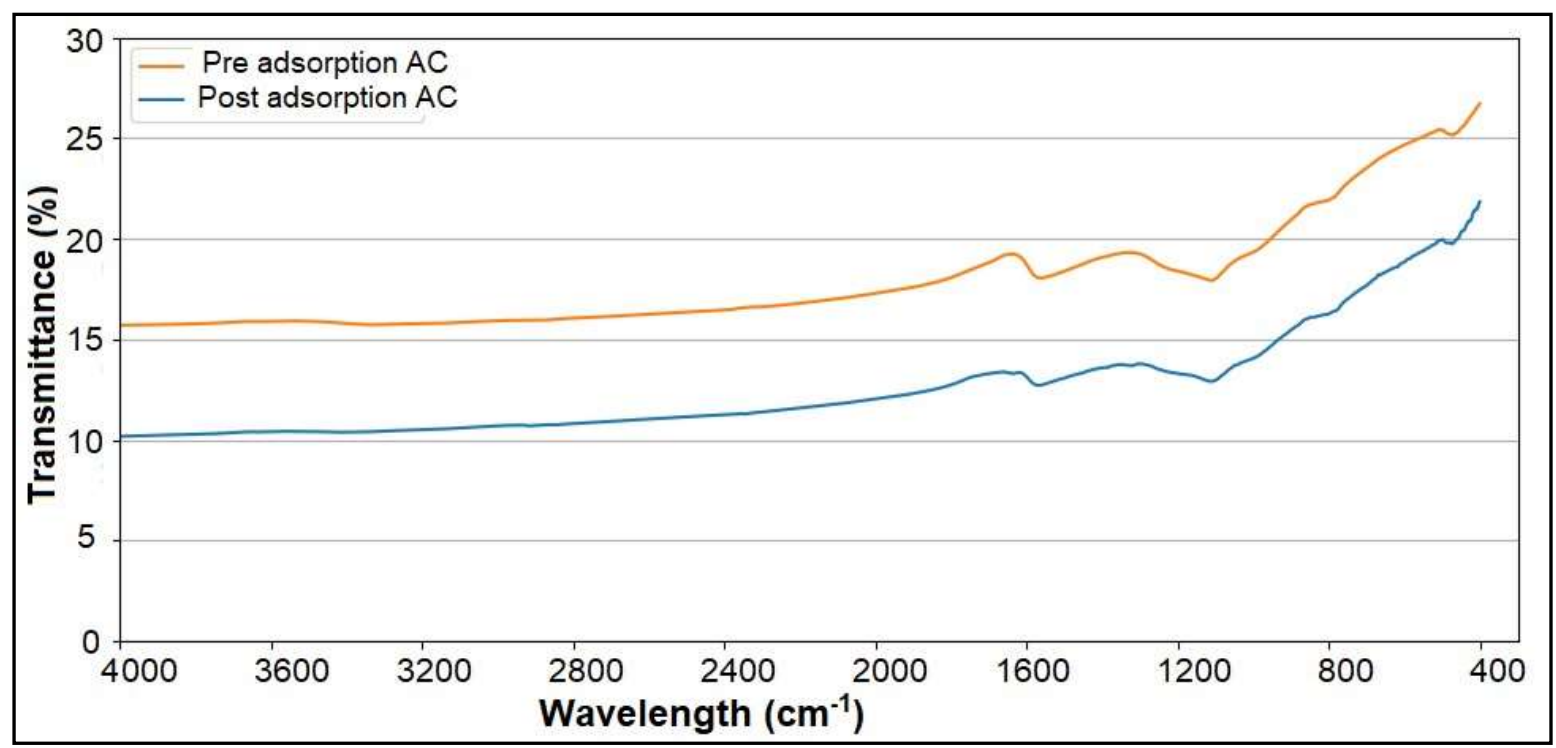

The complex mixture of molecules of organic matter varies from small hydrophilic acids, proteins and amino acids to large molecules of humic acid and fulvic acid (antiaging, antioxidant and nutritional agents in cosmetics). One of the factors influencing the adsorption capacity is the accessibility of the organic molecules to the inner surface of the adsorbent, which depends on their sizes. As an example, small molecules such as phenol can access micropores and intermediate molecules of organic matter can access the mesopores. When electrostatic interactions are smaller due to the non-polarity of the organic molecules, the adsorption will be favored by the pore volume of the activated carbon for organic matter with molecular weight between 500 and $3000 \mathrm{u}$ in acidic pH (MORENO-CASTILLA, 2004).

\subsubsection{TG/DTA}

The thermogram for the $A C$ is shown in Fig.7. The occurrence of three mass loss regions associated with thermal events in the DTA curves is observed. The first mass loss area is endothermic at around $100^{\circ} \mathrm{C}$, the second, above $500^{\circ} \mathrm{C}$, may be associated with functional groups on the surface, especially those having carbon and oxygen atoms in the structure, such as lactones, quinones, hydroquinones and phenols (PEGO; CARVALHO; 
GUEDES, 2017). The last one, next to $800^{\circ} \mathrm{C}$, is related with the combustion of charcoal, respectively.

Figure 7 - TG/DTA results for AC

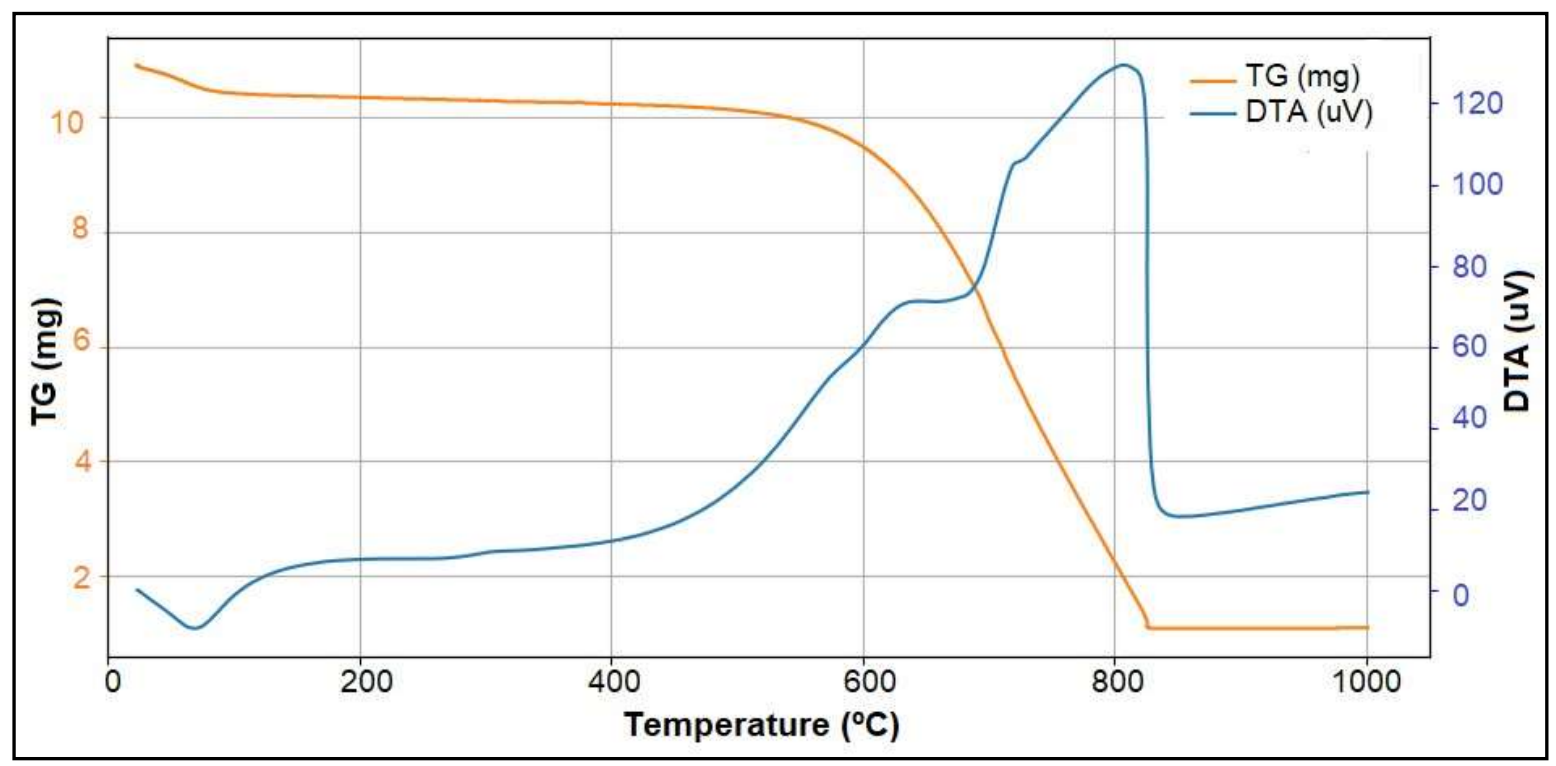

\subsubsection{Boehm titration and surface groups}

The surface functional groups were quantified by Boehm titration method (BOEHM, 1994). The Boehm titration experiments have shown that the AC surface is characterized almost equally by carboxylic acid groups $(0.6 \mathrm{mmol} \mathrm{g}-1)$, phenolic acid groups $(0.4 \mathrm{mmol}$ $\mathrm{g}-1)$ and lactone acid groups $(0.5 \mathrm{mmol} \mathrm{g}-1)$. These functional groups are considered to be the major sources of surface acidity because they are closely related to oxygen-containing surface groups. These oxygen-containing groups are formed when the surface of the activated charcoal is oxidized. The most commonly used activation methods for the introduction of oxygen-containing acid groups are oxidation by aqueous gases and oxidants. According to the manufacturer, the AC was physically activated with water vapor at high temperature. In this process, the high temperature favors the formation of weak acid groups.

The alkalinity of AC (1.2 mmol g-1) may be associated with: (i) proton-attracting carbon aromatic rings resonance electrons, (ii) basic surface functionalities (such as 
nitrogen-containing groups) that are able to bind with protons, (iii) the presence of delocalized electrons from graphene layers, which may act as Lewis bases (SHAFEEYAN et al., 2010). The total concentration of alkaline sites, $1.2 \mathrm{mmol} \mathrm{g-1,} \mathrm{reflect} \mathrm{the} \mathrm{trend} \mathrm{of} \mathrm{these}$ species for the acid-base behavior of the surface.

\subsubsection{Adsorption kinetics}

The kinetic adsorption data is shown in Figure 8. The contact time of 16 minutes between the phases was necessary for the system to reach equilibrium. Thus, a rapid process compared to the literature, as in Venkata et al (2002) and Malik (2003).

Over time, the percentage of COD removal and turbidity increase due to the adsorption of effluent molecules at the available active sites. After reaching equilibrium, the active sites are already saturated and the percentage of removal in the values of the environmental parameters remains constant (BULUT; KARAER, 2015).

Figure 8 - Equilibrium time for the adsorption treatment applied on a cosmetic industry wastewater sample

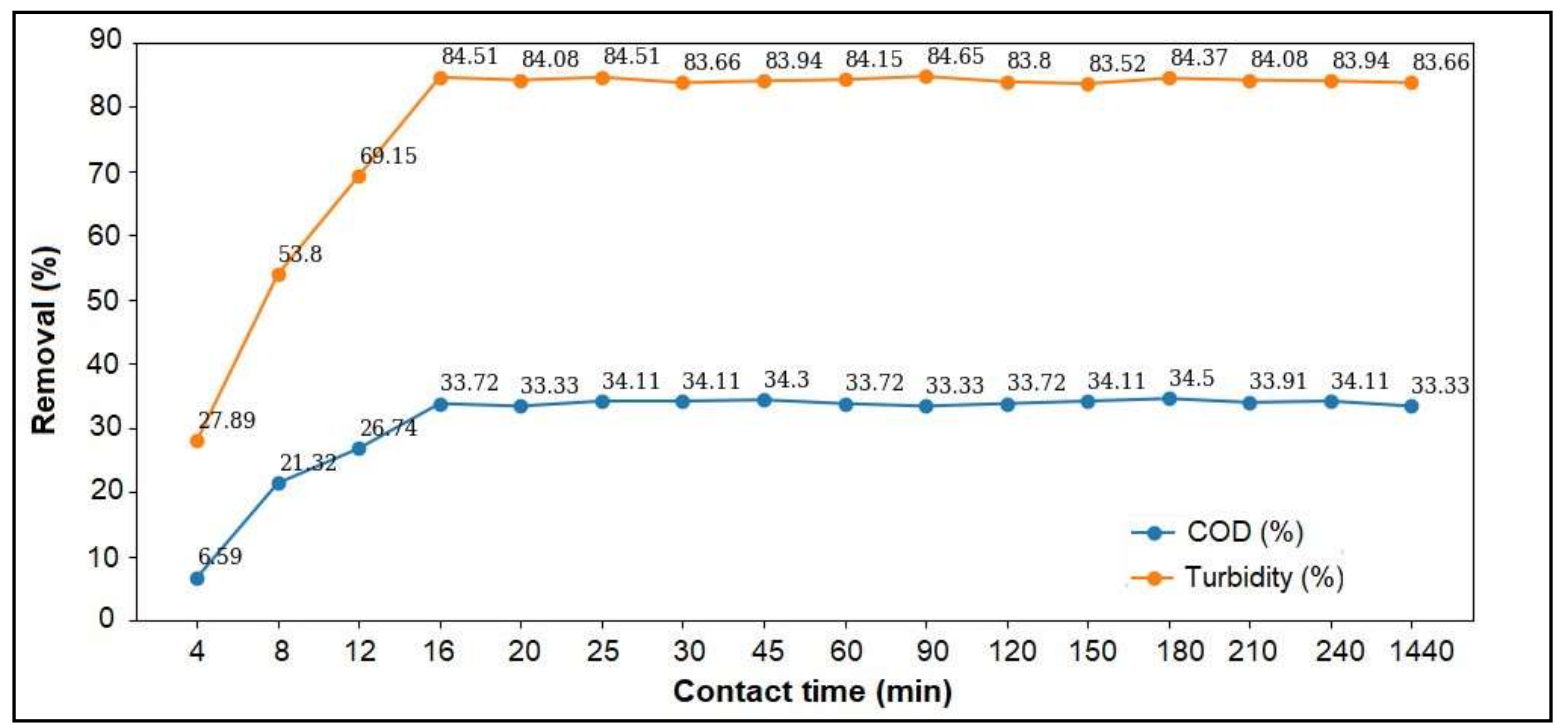

Normally, the relationship between temperature and adsorptive capacity increases or decreases the adsorption rate with increasing temperature. In this study, there was no significant increase or decrease with temperature variation. There may have been an 
increase in the number of adsorption sites caused by disruption of some of the inner bonds near the edge of the active surface of the adsorbent. Moreover, if adsorption is controlled by the diffusion process (intraparticle transport and diffusion in the pores), the sorption capacity increases with increasing temperature due to the endothermicity of the diffusion process (GAUTAM; ALAM; KAMSONLIAN, 2016). However, it is likely that the interacting forces between the effluent substances themselves have become stronger than the adsorbate-adsorbent interactions (ALEBOREE; ALSHIRIFI; ALKAIM, 2017). In addition, there is an increase in the affinity of water molecules for organic compounds as the temperature increases (BLACK; MULLER, 2010).

\subsection{Effluent Final Characterization}

The overall percentages of removal and increase of environmental control parameters are presented in Table 2.

Table 2 - Effluent characterization after Fenton process (H2O2: 1300 mg L-1; Fe2+:

$184.21 \mathrm{mg} \mathrm{L}-1 ; \mathrm{pH}: 3.5)$ and adsorption treatments $\left(\mathrm{T}: 30^{\circ} \mathrm{C}, 120 \mathrm{rpm}\right.$, contact time:

$16 \mathrm{~min})$. Positive values means reduction of parameters as negative means an increase

\begin{tabular}{|c|c|c|c|c|}
\hline \multicolumn{2}{|c|}{ Environmental parameter } & $\begin{array}{c}\text { After } \\
\text { Fenton } \\
\text { process (\%) }\end{array}$ & $\begin{array}{c}\text { After } \\
\text { adsorption } \\
\text { (\%) }\end{array}$ & $\begin{array}{c}\text { Overall } \\
\text { variation (\%) }\end{array}$ \\
\hline \multicolumn{2}{|l|}{ COD (mg L-1) } & +57.91 & +37.21 & +73.58 \\
\hline \multicolumn{2}{|l|}{ Turbidity (NTU) } & +68.58 & +92.54 & +97.65 \\
\hline \multicolumn{2}{|c|}{ Conductivity (mS cm-1) } & -79.02 & +47.14 & +5.36 \\
\hline \multicolumn{2}{|c|}{ Dissolved oxygen (mg L-1) } & -104.04 & -18.23 & -141.24 \\
\hline \multicolumn{2}{|c|}{ Total phenols (mg L-1) } & +64.97 & +49.64 & +81.77 \\
\hline \multicolumn{2}{|c|}{ Total iron (mg L-1) } & +60.12 & +24.69 & +69.97 \\
\hline \multicolumn{2}{|c|}{ Hydrogen peroxide (mg L-1) } & +97.58 & +14.73 & +97.78 \\
\hline \multirow{3}{*}{ Solids (mg L-1) } & Total & +32.36 & +20.71 & +46.37 \\
\hline & Fixed Total & +20.75 & +12.38 & +30.57 \\
\hline & Volatile Total & +32.57 & +20.89 & +46.65 \\
\hline
\end{tabular}




\begin{tabular}{l|l|l|l|l}
\hline \multirow{2}{*}{ Absorbance } & $200 \mathrm{~nm}$ & +23.99 & +45.71 & +36.38 \\
\cline { 2 - 5 } & $400 \mathrm{~nm}$ & +50.35 & +54.42 & +77.37 \\
\hline
\end{tabular}

The low initial concentration (3.71 mg L-1) of dissolved oxygen in the system can be explained by the high concentration of initial organic matter. However, the increase in dissolved oxygen concentration $(7.57 \mathrm{mg} \mathrm{L}-1)$ may have occurred not only by the mineralization of organic compounds, but also by the generation of molecular oxygen in Fenton oxidation/reduction reactions during Fe2+ ion regeneration reactions (Eq. 20 and 21) (MORAIS; BRITO, 2015) and through intermediate species (Eq. 10 and 11) (PLIEGO et al., 2015).

$$
\begin{aligned}
& \mathrm{Fe} 3++\mathrm{OOH} \cdot \rightarrow \mathrm{Fe} 2++\mathrm{H}++\mathrm{O} 2 \mathrm{k}=1.5 .105 \mathrm{~L} \mathrm{~mol}-1 \mathrm{~s}-1(20) \\
& \mathrm{Fe} 3++\mathrm{O} 2 .-\rightarrow \mathrm{Fe} 2++\mathrm{O} 2 \mathrm{k}=5.0 .107 \mathrm{~L} \mathrm{~mol}-1 \mathrm{~s}-1(21)
\end{aligned}
$$

It is important to note that the DO (dissolved oxygen) concentration may increase in treated effluent once the residual hydrogen peroxide present releases water and oxygen gas in its decomposition. It is also worth noticing that an increase in DO concentration may be caused by aeration in the jar test and a decrease in organic matter concentration.

The Fenton process treatment also achieved satisfactory removal rates, with turbidity removal and phenolic compounds above $65 \%$ and COD of about $58 \%$. The removal of $58 \%$ of the COD indicates that the Fenton process technology is efficient in treating effluent from the cosmetic industry. Similar results were found by Marcinowski et al. (2014) and Bautista et al. (2014).

It is important to highlight that the presence of hydrolysed ferrous ions produces a series of complexes which plays the role of a flake-maker coagulants, which somehow enhances the removal efficiency in the turbidity and absorbance. This procedure demonstrates the dual ability of the Fenton process in acting as both chemical oxidation process and coagulation/flocculation process (MORAIS; BRITO, 2015).

Prior to the Fenton process, all samples $\mathrm{pH}$ were adjusted to 3.5 (initial pH). However, the $\mathrm{pH}$ after the Fenton treatment was equal to 3.42 (final $\mathrm{pH}$ ). The difference between 
initial and final $\mathrm{pH}$ is justified by the release of $\mathrm{H}+$ ions during the treatment due to regeneration of ferrous ions (BABUPONNUSAMI; MUTHUKUMAR, 2014; GIANNAKIS et al., 2016; SOHRABI et al., 2017) (Eq. 4).

The release of protons in the medium is also triggered by the decomposition of the hydroperoxyl radical (Eq. 22) (GIANNAKIS et al., 2016).

$\mathrm{HO} 2 • \leftrightarrows \mathrm{O} 2 \bullet-+\mathrm{H}+\mathrm{k}=1.58 \times 105 \mathrm{~L} \mathrm{~mol}-1 \mathrm{~s}-1(22)$

The reaction between ferric ion and the hydroperoxyl radical leads to the regeneration of ferrous ions with liberation of oxygen gas and $\mathrm{H}+$ ions, as shown in Eq. 20 (BABUPONNUSAMI; MUTHUKUMAR, 2014).

The increase of electrical conductivity can be related to the addition of ions in the system during the Fenton's reaction and its oxidation-reduction reactions. In addition, there is formation of intermediate species during the mineralization of the organic compounds that may increase $(+79 \%)$ the value of this parameter.

Although the initial effluent did not present total iron concentration, the presence of iron ions is fundamental for the occurrence of the treatment through Fenton process, acting in a catalytic cycle of the reactions. In this case, $184.21 \mathrm{mg} \mathrm{L}-1$ of Fe2+ was added during the process, and the final concentration was $73.46 \mathrm{mg} \mathrm{L}-1$.

The CONAMA Resolution 430 determines a maximum permissible value of $15 \mathrm{mg} \mathrm{L-1}$ of total iron for disposal purposes in hidric bodies (BRASIL, 2011). Thus, the concentration of soluble iron does not reach the parameters determined by legislation. However, it is well known that Fenton active specie $\mathrm{Fe} 2+$ is oxidized to $\mathrm{Fe} 3+$ by the dissolved oxygen present in water that could be removed by a coagulation process (PERDIGÓN-MELÓN et al., 2010).

The addition of residual hydrogen peroxide, as well as iron, is one of the factors that controls Fenton's reagent treatment. The concentration of hydrogen peroxide was initially controlled at $1300 \mathrm{mg} \mathrm{L}-1$. At the end of the process, this concentration decreased to 31.50 $\mathrm{mg} \mathrm{L}-1$, which indicates the consumption of this reagent in the Fenton reactions.

The decrease of this parameter is of great importance since hydrogen peroxide acts as an oxidizing agent $(1.77 \mathrm{eV})$. And in this way, the oxidation process would continue to 
occur in aqueous medium if the hydrogen peroxide did not decompose rapidly into water and oxygen (ANDRADE et al., 2015).

The decrease in the absorbance values for the studied wavelengths indicates the complete or partial mineralization of the chromophore groups by the attack of the hydroxyl radicals, which is in agreement with the percentage of removal of organic matter observed (TANG, 2003). It has been stated (SOHRABI et al., 2017) that the absorbance at the $200 \mathrm{~nm}$ peak is related to the $\pi-\pi^{*}$ transitions in aromatic compounds, which are characteristics of organic dyes. At $400 \mathrm{~nm}$, the reduction of absorbance indicates the removal of the chromophore groups, which strongly absorb in this region (WANG et al., 2016). The overall final removals of absorbance in this study were $24 \%$ at $200 \mathrm{~nm}$ and $50 \%$ at $400 \mathrm{~nm}$ for 66 minutes of treatment.

The removal of total phenols occurs by the hydroxyl radicals attacking the organic compound by the electron abstraction of the $\pi$ bond of the aromatic ring, leading to its mineralization (65\% of removal in this treatment) (KAVITHA; PALANIVELU, 2016). It has been shown (FENG et al., 2017) that the phenolic mineralization chain reaction via Fenton process depends on the reduction of $\mathrm{Fe} 3+$ ions by polyphenol type intermediates.

In this cycle, $\mathrm{Fe} 2+$ is continuously generated by the reduction of $\mathrm{Fe} 3+$ to $\mathrm{Fe} 2+$, while $\mathrm{Fe} 2+$ is oxidized to $\mathrm{Fe} 3+$ in the presence of $\mathrm{H} 2 \mathrm{O} 2$ and produces hydroxyl radicals. In this process, phenol is oxidized to hydroquinone and the Fenton reaction is accelerated by its characteristic regeneration of the $\mathrm{Fe} 2+/ \mathrm{Fe} 3+$. Since the $\mathrm{Fe} 3+$ reduction rate is a determining factor in the Fenton cyclic process, degradation of phenol is facilitated at the same time as more polyphenol intermediates are generated. In turn, more intermediates of polyphenols lead to a faster reduction of $\mathrm{Fe} 3+$ and degradation of phenol is even more accelerated.

The analysis of the solid series revealed that for this type of effluent no settleable solids were found. However, there was a $33 \%$ reduction of total volatile solids. This result is significant and represents an estimate of organic matter present in the effluent (MUNOZ et al., 2012). Also according to CONAMA Resolution 430 (BRASIL, 2011), the efficiency in the total suspended solids removal must meet the minimum rate of $20 \%$ removal after 
desanding. In the treatment carried out, total suspended solid removals reached $32 \%$, which describes the treatment as highly effective in removing total solids.

In terms of adsorption, the decrease in COD value indicates the adsorption of organic compounds in the pores of the adsorbent. Acids, in effluent for instance, are partially in neutral molecular form and partially in anions (AYRANCl; DUMAN, 2006). In this case, the adsorption occurs both by the electrostatic attraction between the positively charged surface of the activated charcoal and the anionic adsorbate species as well as by the dispersion between the surface of the activated charcoal and the neutral adsorbate molecules.

The increase of the dissolved oxygen concentration is an indirect proof of the removal of organic particles, since this parameter has low concentration in effluents with high organic matter once it is used for its decomposition.

The biggest source of turbidity in effluents are the particles in suspension. Therefore, it is correct to state that the decrease in turbidity indicates the removal of suspended solids (AMOSA et al., 2016). Similarly, the decrease in total solids indicates removal of both organic and inorganic substances. Because the volatile solids were more adsorbed, it is possible to assume that adsorption of organic substances occurred preferentially.

The reduction of electrical conductivity indicates removal of dissolved inorganic salts, such as sulfates, sodium salts, carbonates and chlorides, and dissociated ions present in the effluent. This is confirmed by the removal of dissolved solids, since there is a correlation between the amount of dissolved solids and the electrical conductivity observed in aqueous solutions (HUBERT; WOLKERSDORFER, 2015).

In terms of absorbance, activated carbons are materials with an amphoteric character, in the same way as it was observed with the activated charcoal used in this study (FARIA; ÓRFÃO; PEREIRA, 2004). Thus, depending on the pH of the solution, its surfaces can be charged either positively or negatively. When $\mathrm{pH}>\mathrm{pHPZC}$, the surface of the activated charcoal becomes negatively charged, which favors the adsorption of cationic species. On the other hand, the adsorption of anionic species is favored at $\mathrm{pH}<\mathrm{pHPZC}$. That is, if electrostatic interactions are the main adsorption mechanism, cationic dyes tend to have 
higher affinity with acidic surfaces and anionic dyes adsorb preferentially on alkaline surface in activated carbon samples.

The adsorption of almost $50 \%$ of total phenols is in agreement with several studies in the literature that confirm the efficiency of the adsorption of phenolic compounds in activated charcoal (RENGARAJ et al., 2002; DUAN et al., 2015; XIONG et al., 2018). It has been evaluated (AHMARUZZAMAN; SHARMA, 2005) that the adsorption of phenols on an amphoteric surface (such as the activated charcoal of this study) from an aqueous solution depends on two factors: the dissociation of the electrolytes in the solution and the dominant charge on the activated charcoal surface. As phenols are weak electrolytes and do not dissociate at acidic $\mathrm{pH}$, they are adsorbed in molecular form.

\section{Conclusions}

The integration of the technologies obtained a greater efficiency in the treatment of the effluent of cosmetics if compared to the application of the technologies in an individualized way and it showed the importance of the integration of the same ones in the minimization of the environmental impact.

Fenton process treatment obtained significant removal values for parameters such as COD, turbidity, total phenols and total volatile solids, due to the inherent oxidative character of the technology that reduces the phase transfer of pollutants. In this work, the $[\mathrm{Fe} 2+/ \mathrm{H} 2 \mathrm{O} 2]$ ratio was 1: 7.06 , which confirms the high contaminant power of the effluent in question.

In addition to supplementing COD removal, turbidity, total solids, total phenols and absorbance, the adsorption acted in a complementary manner to the Fenton process correcting parameters that varied negatively. The conductivity, for example, which increased with the release of ions during the Fenton process tests, decreased with the application of adsorption onto the post-Fenton effluent. The $\mathrm{pH}$, which became more acidic during Fenton treatment, increased during the adsorption application and hydrogen peroxide, added to the Fenton treatment, it had its concentration reduced by the 
adsorption process. Thus, it suggests an increase in the treatment line with more integrations of advanced technologies applying adsorption as final polishing.

\section{Acknowledgements}

The authors are grateful to CAPES (Coordination for the Improvement of Higher Education Personnel, Code 001), CNPq (National Council for Scientific and Technological Development, 444920/2014-5) and the Foundation for Research Support of the State of Goias - Fundação de Amparo à Pesquisa do Estado de Goiás, FAPEG) by students financial support.

\section{References}

AHMARUZZAMAN, M.; SHARMA, D. K. Adsorption of phenols from wastewater. Journal of Colloid and Interface Science, v. 287, n. 1, p. 14-24, 2005.

ALJEBOREE, A. M.; ALSHIRIFI, A. N.; ALKAIM, A. F. Kinetics and equilibrium study for the adsorption of textile dyes on coconut shell activated carbon. Arabian Journal of Chemistry, v. 10, p. S3381-S3393, 2017.

AMOSA, M. K.; JAMI, M. S.; ALKHATIB, M. F. R.; TAJARI, T.; JIMAT, D. N.; OWOLABI, R. U. Turbidity and suspended solids removal from high-strength wastewater using high surface area adsorbent: Mechanistic pathway and statistical analysis. Cogent Engineering, v. 3, n. 1, p. 1162384, 2016.

ANDRADE, P. M.; CARVALHO, M. A. F.; MIRANDA, A. S.; MARQUES, H. R.; CAMPOS, S. R.; BRITO, N. Remediation of textile dyes mixtures using TiO2/Vis Photocatalysis and Fenton $\mathrm{Fe} 2+/ \mathrm{H} 2 \mathrm{O} 2$. Brazilian Journal of Biosystems Engineering, v. 9, n. 4, p. 328-338, 2015.

APHA. Standard methods for the examination of water and wastewater. American Public Health Association, American Water Works Association, Water Environmental Federation, 20 ed. Washington, 1998.

AYRANCI, E.; DUMAN, O. Adsorption of aromatic organic acids onto high area activated carbon cloth in relation to wastewater purification. Journal of Hazardous Materials, v. 136, n. 3, p. 542-552, 2006.

BABUPONNUSAMI, A.; MUTHUKUMAR, K. A review on Fenton and improvements to the Fenton process for wastewater treatment. Journal of Environmental Chemical

Engineering, v. 2, n. 1, p. 557-572, 2014. 
BARRETT, E. P.; JOYNER, L. G.; HALENDA, P. P. The Determination of Pore Volume and Area Distributions in Porous Substances. I. Computations from Nitrogen Isotherms. Journal of the American Chemical Society, v. 73, n. 1, p. 373-380, 1951.

BAUTISTA, P.; CASAS, J. A.; ZAZO, J. A.; RODRIGUEZ, J. J.; MOHEDANO, A. F. Comparison of Fenton and Fenton-like oxidation for the treatment of cosmetic wastewater. Water Science and Technology, v. 70, n. 3, p. 472-478, 2014.

BEHVANDI, A.; SAFEKORDI, A. A.; KHORASHEH, F. Removal of benzoic acid from industrial wastewater using metal organic frameworks: equilibrium, kinetic and thermodynamic study. Journal of Porous Materials, v. 24, n. 1, p. 165-178, 2017.

BERGER, K. P.; KOGUT, K. R.; BRADMAN, A.; SHE, J.; GAVIN, Q.; ZAHEDI, R.; PARRA, K. L.; HARLEY, K. G. Personal care product use as a predictor of urinary concentrations of certain phthalates, parabens, and phenols in the HERMOSA study. Journal of Exposure Science \& Environmental Epidemiology, 2018.

BLACK, S.; MULLER, F. On the Effect of Temperature on Aqueous Solubility of Organic Solids. Organic Process Research \& Development, v. 14, n. 3, p. 661-665, 2010.

BOEHM, H. P. Some aspects of the surface chemistry of carbon blacks and other carbons. Carbon, v. 32, n. 5, p. 759-769, 1994.

BOHLI, T.; OUEDERNI, A. Improvement of oxygen-containing functional groups on olive stones activated carbon by ozone and nitric acid for heavy metals removal from aqueous phase. Environmental Science and Pollution Research, v. 23, n. 16, p. 15852-15861, 2016.

BRASIL. Resolução no 430, de 13 de maio de 2011. Conselho Nacional do Meio Ambiente. Dispõe sobre condições e padrões de lançamento de efluentes, complementa e altera a Resolução no 357, de 17 de março de 2005.

BULUT, Y.; KARAER, H. Adsorption of Methylene Blue from Aqueous Solution by Crosslinked Chitosan/Bentonite Composite. Journal of Dispersion Science and Technology, v. 36, n. 1, p. 61-67, 2015.

CHENG, S.; ZHANG, L.; XIA, H.; ZHANG, S.; PENG, J.; WANG, S. Crofton weed derived activated carbon by microwave-induced $\mathrm{KOH}$ activation and application to wastewater treatment. Journal of Porous Materials, v. 23, n. 6, p. 1597-1607, 2016.

CHIANG, H.-L.; HUANG, C. P.; CHIANG, P. C. The surface characteristics of activated carbon as affected by ozone and alkaline treatment. Chemosphere, v. 47, n. 3, p. 257-265, 2002. 
CINCINELLI, A.; MARTELLINI, T.; COPPINI, E.; FIBBI, D.; KATSOYIANNIS, A. Nanotechnologies for Removal of Pharmaceuticals and Personal Care Products from Water and Wastewater. A Review. Journal of Nanoscience and Nanotechnology, v. 15, 2015.

DAFFALA, S.; MUKHTAR, H.; SHAHARUN, M. Characterization of Adsorbent DEveloped from Rice Husk: Effect of Surface Function Group on Phenol Adsorption. Journal of Applied Sciences, v. 10, n. 12, p. 1060-1067, 2010.

DE ANDRADE, P.; RAFAEL DUFRAYER, C.; DE BRITO, N. Treatment of Real Cosmetic Effluent Resulting from the Manufacture of Hair Conditioners by Reduction Degradation, Adsorption and the Fenton Reaction. Ozone: Science \& Engineering, p. 110, 2018.

DE OLIVEIRA FERREIRA, M. E.; VAZ, B. G.; BORBA, C. E.; GONÇALVES, C.; CONCEIÇÃO, I. Microporous and Mesoporous Materials Modified activated carbon as a promising adsorbent for quinoline removal. Microporous and Mesoporous Materials, v. 277, n. November 2018, p. 208-216, 2019.

DHILLON, G. S.; KAUR, S.; PULICHARLA, R.; BRAR, S. K.; CLEDÓN, M.; VERMA, M.; SURAMPALLI, R. Y. Triclosan: Current status, occurrence, environmental risks and bioaccumulation potential. International Journal of Environmental Research and Public Health, v. 12, n. 5, p. 5657-5684, 2015.

DUAN, F.; LI, Y.; CAO, H.; WANG, Y.; CRITTENDEN, J. C.; ZHANG, Y. Activated carbon electrodes: Electrochemical oxidation coupled with desalination for wastewater treatment. Chemosphere, v. 125, p. 205-211, 2015.

ELMOLLA, E. S.; CHAUDHURI, M. Combined photo-Fenton-SBR process for antibiotic wastewater treatment. Journal of Hazardous Materials, v. 192, n. 3, p. 1418-1426, 2011.

ERKAN, G. K. A. H. S.; TOP, E. S. S.; BILGILI, H. K. M. S. Modeling and optimizing Fenton and electro - Fenton processes for dairy wastewater treatment using response surface methodology. International Journal of Environmental Science and Technology, v. 16, n. 5, p. 2343-2358, 2019..

FARIA, P. C. C.; ÓRFÃO, J. J. M.; PEREIRA, M. F. R. Adsorption of anionic and cationic dyes on activated carbons with different surface chemistries. Water Research, v. 38, n. 8, p. 20432052, 2004.

FENG, J.; LI, S.; SHENG, Y.; XIONG, Y.; LAN, S.; TIAN, S.; KONG, L.; FAN, C. Remarkable improvement of cycling Fenton process for catalytic degradation of phenol: Tuning of triggering effect. Applied Catalysis A: General, v. 542, p. 21-27, 2017. 
FONTMORIN, J.-M.; SILLANPÄÄ, M. Dewatering and removal of metals from urban anaerobically digested sludge by Fenton's oxidation. Environmental Technology, v. 38, n. 4, p. 495-505, 16 fev. 2017.

GANZENKO, O.; OTURAN, N.; SIRÉS, I.; HUGUENOT, D.; VAN HULLEBUSCH, E. D.; ESPOSITO, G.; OTURAN, M. A. Fast and complete removal of the 5 -fluorouracil drug from water by electro-Fenton oxidation. Environmental Chemistry Letters, v. 16, n. 1, p. 281-286, 2018.

GAUTAM, S. B.; ALAM, S.; KAMSONLIAN, S. Adsorption of As ( III ) on Iron Coated Quartz Sand: Influence of Temperature on the Equilibrium Isotherm, Thermodynamics and Isosteric Heat of Adsorption Analysis. International Journal of Chemical Reactor Engineering, v. 14, n. 1, p. 289-298, 2016.

GIANNAKIS, S.; LÓPEZ, M. I. P.; SPUHLER, D.; PÉREZ, J. A. S.; IBÁÑEZ, P. F.; PULGARIN, C. Solar disinfection is an augmentable, in situ-generated photo-Fenton reaction-Part 1: A review of the mechanisms and the fundamental aspects of the process. Applied Catalysis B: Environmental, v. 199, p. 199-223, 2016.

GUO, J.-S.; ABBAS, A. A.; CHEN, Y.-P.; LIU, Z.-P.; FANG, F.; CHEN, P. Treatment of landfill leachate using a combined stripping, Fenton, SBR, and coagulation process. Journal of Hazardous Materials, v. 178, n. 1, p. 699-705, 2010.

GÜRSES, A.; AÇIKYILDIZ, M.; GÜNEŞ, K.; GÜRSES, M. S. Dyes and pigments. Cham: Springer International Publishing, 2016.

HUBERT, E.; WOLKERSDORFER, C. Establishing a conversion factor between electrical conductivity and total dissolved solids in South African mine waters. Water SA, v. 41, n. 4, p. 490-500, 2015.

KAVITHA, V.; PALANIVELU, K. Degradation of phenol and trichlorophenol by heterogeneous photo-Fenton process using Granular Ferric Hydroxide ${ }^{\circledR}$ : comparison with homogeneous system. International Journal of Environmental Science and Technology, v. 13, n. 3, p. 927-936, 2016.

KIM, H.; KO, Y.; LEE, S.; HONG, S. W.; LEE, W.; CHOI, J. Degradation of Organic Compounds in Actual Wastewater by Electro-Fenton Process and Evaluation of Energy Consumption, 2018.

LEE, M.; NAM, K. T.; KIM, J.; LIM, S. E.; YEON, S. H.; LEE, B.; LEE, J. Y.; LIM, K.-M. Evaluation of ocular irritancy of coal-tar dyes used in cosmetics employing reconstructed human cornealike epithelium and short time exposure tests. Food and Chemical Toxicology, v. 108, p. 236-243, 2017. 
LI, L.; QUINLIVAN, P. A.; KNAPPE, D. R. U. Effects of activated carbon surface chemistry and pore structure on the adsorption of organic contaminants from aqueous solution. Carbon, v. 40, n. 12, p. 2085-2100, 2002.

LIPPENS, B. C.; DE BOER, J. H. Studies on pore systems in catalysts: V. The t method. Journal of Catalysis, v. 4, n. 3, p. 319-323, 1965.

LYU, C.; ZHOU, D.; WANG, J. Removal of multi-dye wastewater by the novel integrated adsorption and Fenton oxidation process in a fluidized bed reactor. Environmental Science and Pollution Research, p. 20893-20903, 2016.

MA, J.; HUANG, D.; ZOU, J.; LI, L.; KONG, Y.; KOMARNENI, S. Adsorption of methylene blue and Orange II pollutants on activated carbon prepared from banana peel. Journal of Porous Materials, v. 22, n. 2, p. 301-311, 2015.

MA, X.-J.; XIA, H.-L. Treatment of water-based printing ink wastewater by Fenton process combined with coagulation. Journal of Hazardous Materials, v. 162, n. 1, p. 386-390, 2009.

MAILLER, R.; GASPERI, J.; COQUET, Y.; DEROME, C.; BULETÉ, A.; VULLIET, E.; BRESSY, A.; VARRAULT, G.; CHEBBO, G.; ROCHER, V. Removal of emerging micropollutants from wastewater by activated carbon adsorption: Experimental study of different activated carbons and factors influencing the adsorption of micropollutants in wastewater. Journal of Environmental Chemical Engineering, v. 4, n. 1, p. 1102-1109, 2016.

MALIK, P. K. Use of activated carbons prepared from sawdust and rice-husk for adsorption of acid dyes: a case study of Acid Yellow 36. Dyes and Pigments, v. 56, n. 3, p. 239-249, 2003.

MANOCHA, S.; MOVALIYA, N. Studies on Pore Characteristics of Microporous Carbons Prepared with Different Types of Silica Templates. v. 8, n. 1, p. 17-24, 2007.

MARCINOWSKI, P. P.; BOGACKI, J. P.; NAUMCZYK, J. H. Cosmetic wastewater treatment using the Fenton, photo-Fenton and $\mathrm{H}$ 2O2/UV processes. Journal of Environmental Science and Health - Part A Toxic/Hazardous Substances and Environmental Engineering, v. 49, n. 13, p. 1531-1541, 2014.

MAZARJI, M.; AMINZADEH, B.; BAGHDADI, M.; BHATNAGAR, A. Removal of nitrate from aqueous solution using modified granular activated carbon. Journal of Molecular Liquids, v. 233, p. $139-148,2017$.

MELO, N. H. De; DE OLIVEIRA FERREIRA, M. E.; NETO, E. M. S.; MARTINS, P. R.; OSTROSKI, I. $C$. Environmental Nanotechnology, Monitoring \& Management Evaluation of the adsorption process using activated bone char functionalized with magnetite 
nanoparticles. Environmental Nanotechnology, Monitoring \& Management, v. 10, n. August, p. 427-434, 2018.

MOOSA, A. A.; RIDHA, A. M.; KADHIM, N. A. Use of Biocomposite Adsorbents for the Removal of Methylene Blue Dye from Aqueous Solution. American Journal of Materials Science, v. 6, n. 5, p. 135-146, 2016.

MORAIS, W. O.; BRITO, N. N. Treatment of simulated wastewater via fenton reaction at a production line of sunscreen. Oxidation Communications, v. 38, n. 4A, p. 2261-2272, 2015.

MORENO-CASTILLA, C. Adsorption of organic molecules from aqueous solutions on carbon materials. Carbon, v. 42, n. 1, p. 83-94, 2004.

MUNOZ, M.; DE PEDRO, Z. M.; PLIEGO, G.; CASAS, J. A.; RODRIGUEZ, J. J. Chlorinated Byproducts from the Fenton-like Oxidation of Polychlorinated Phenols. Industrial \& Engineering Chemistry Research, v. 51, n. 40, p. 13092-13099, 2012.

NAUMCZYK, J.; BOGACKI, J.; MARCINOWSKI, P.; KOWALIK, P. Cosmetic wastewater treatment by coagulation and advanced oxidation processes. Environmental Technology, v. 35, n. 5, p. 541-548, 2014.

NORDIN, N.; HO, L.; ONG, S.; IBRAHIM, A. H.; WONG, Y.; LEE, S.; OON, Y.; OON, Y. Influence of Amaranth dye concentration on the efficiency of hybrid system of photocatalytic fuel cell and Fenton process. p. 23331-23340, 2017.

OCAÑA-GONZÁLEZ, J. A.; VILLAR-NAVARRO, M.; RAMOS-PAYÁN, M.; FERNÁNDEZTORRES, R.; BELLO-LÓPEZ, M. A. New developments in the extraction and determination of parabens in cosmetics and environmental samples. A review. Analytica Chimica Acta, v. 858, p. 1-15, 2015.

OLIVEIRA, M. C.; NOGUEIRA, R. F. P.; NETO, J. A. G.; JARDIM, W. F.; ROHWEDDER, J. J. R. Flow injection spectrophotometric system for hydrogen peroxide monitoring in photoFenton degradation processes. Química Nova, v. 24, n. 2, p. 188-190, 2001.

OLIVEIRA, T. D.; MARTINI, W. S.; SANTOS, M. D. R.; MATOS, M. A. C.; ROCHA, L. L. Caffeine Oxidation in Water by Fenton and Fenton-Like Processes: Effects of Inorganic Anions and Ecotoxicological Evaluation on Aquatic Organisms. J. Braz. Chem. Soc., v. 26, n. 1, p. 178184, 2015.

OTURAN, M. A.; AARON, J.-J. Advanced Oxidation Processes in Water/Wastewater Treatment: Principles and Applications. A Review. Critical Reviews in Environmental Science and Technology, v. 44, n. 23, p. 2577-2641, 2014. 
PARIENTE, M. I.; MOLINA, R.; MELERO, J. A.; BOTAS, J. Á.; MARTÍNEZ, F. Intensified-Fenton process for the treatment of phenol aqueous solutions. Water Science and Technology, $v$. 71, n. 3, p. 359, 2014.

PARK, J.; REGALBUTO, J. R. A Simple, Accurate Determination of Oxide PZC and the Strong Buffering Effect of Oxide Surfaces at Incipient Wetness. Journal of Colloid and Interface Science, v. 175, n. 1, p. 239-252, 1995.

PAWAR, V.; GAWANDE, S. An overview of the Fenton Process for Industrial Wastewater. Journal of Mechanical and Civil Engineering, p. 127-136, 2015.

PEGO, M.; CARVALHO, J.; GUEDES, D. SURFACE MODIFICATIONS OF ACTIVATED CARBON AND ITS IMPACT ON APPLICATION. Surface Review and Letters, v. 1830006, p. 1-10, 2017.

PERDIGÓN-MELÓN, J. A.; CARBAJO, J. B.; PETRE, A. L.; ROSAL, R.; GARCÍA-CALVO, E. Coagulation-Fenton coupled treatment for ecotoxicity reduction in highly polluted industrial wastewater. Journal of Hazardous Materials, v. 181, n. 1, p. 127-132, 2010.

PEREIRA, C. A. M.; BRITO, N. N. Integration of treatment technologies with Fenton reagent for laboratory effluent remediation. Ambiente e Agua - An Interdisciplinary Journal of Applied Science, v. 13, n. 5, p. 1,2018.

PLIEGO, G.; ZAZO, J. A.; GARCIA-MUÑOZ, P.; MUNOZ, M.; CASAS, J. A.; RODRIGUEZ, J. J. Trends in the Intensification of the Fenton Process for Wastewater Treatment: An Overview. Critical Reviews in Environmental Science and Technology, v. 45, n. 24, p. 2611-2692, 2015.

PUYOL, D.; MONSALVO, V. M.; MOHEDANO, A. F.; SANZ, J. L.; RODRIGUEZ, J. J. Cosmetic wastewater treatment by upflow anaerobic sludge blanket reactor. Journal of Hazardous Materials, v. 185, n. 2, p. 1059-1065, 2011.

RAGASSON, M. K. Fenton's Reagent Application in the Treatment of Leachate from Landfills. Especialize (revista on line), v. 4, n. 1, p. 1-5, 2013.

RENGARAJ, S.; MOON, S.-H.; SIVABALAN, R.; ARABINDOO, B.; MURUGESAN, V. Agricultural solid waste for the removal of organics: adsorption of phenol from water and wastewater by palm seed coat activated carbon. Waste Management, v. 22, n. 5, p. 543-548, 2002.

RIO, S.; FAUR-BRASQUET, C.; LE, L.; COURCOUX, P.; LE, P. Experimental design methodology for the preparation of carbonaceous sorbents from sewage sludge by chemical activation - application to air and water treatments. Chemosphere, v. 58, p. 423-437, 2005. 
RODRIGUES, C. S. D.; NETO, A. R.; DUDA, R. M.; DE OLIVEIRA, R. A.; BOAVENTURA, R. A. R.; MADEIRA, L. M. Combination of chemical coagulation, photo-Fenton oxidation and biodegradation for the treatment of vinasse from sugar cane ethanol distillery. Journal of Cleaner Production, v. 142, p. 3634-3644, 2017.

SHAFEEYAN, M. S.; DAUD, W. M. A. W.; HOUSHMAND, A.; SHAMIRI, A. A review on surface modification of activated carbon for carbon dioxide adsorption. Journal of Analytical and Applied Pyrolysis, v. 89, n. 2, p. 143-151, 2010.

SHETTY, R.; VERMA, S. Fenton 's Reagent for the Treatment of Pharmaceutical Industry Wastewater. International Journal of Science and Research, v. 4, n. 7, p. 3093-3096, 2015.

SOHRABI, M. R.; KHAVARAN, A.; SHARIATI, S.; SHARIATI, S. Removal of Carmoisine edible dye by Fenton and photo Fenton processes using Taguchi orthogonal array design. Arabian Journal of Chemistry, v. 10, p. S3523-S3531, 2017.

SU, E.-C.; HUANG, B.-S.; LIU, C.-C.; WEY, M.-Y. Photocatalytic conversion of simulated EDTA wastewater to hydrogen by $\mathrm{pH}$-resistant $\mathrm{Pt} / \mathrm{TiO} 2-$ activated carbon photocatalysts.

Renewable Energy, v. 75, p. 266-271, 2015.

SUNEETHA, M.; SUNDAR, B. S.; RAVINDHRANATH, K. Removal of fluoride from polluted waters using active carbon derived from barks of Vitex negundo plant. Journal of Analytical Science and Technology, v. 6, n. 1, p. 15, 2015.

TANG, W. Z. Physicochemical treatment of hazardous wastes. Boca Raton, FL: CRC Press, 2003.

VAISHNAVE, P.; KUMAR, A.; AMETA, R.; PUNJABI, P. B.; AMETA, S. C. Photo oxidative degradation of azure-B by sono-photo-Fenton and photo-Fenton reagents. Arabian Journal of Chemistry, v. 7, n. 6, p. 981-985, 2014.

VENKATA, M.S.; CHANDRASEKHAR, R. N.; KARTHIKEYAN, J. Adsorptive removal of direct azo dye from aqueous phase onto coal based sorbents: a kinetic and mechanistic study. Journal of Hazardous Materials, v. 90, p. 189-204, 2002.

WANG, F. A novel magnetic activated carbon produced via hydrochloric acid pickling water activation for methylene blue removal. Journal of Porous Materials, v. 25, n. 2, p. 611619, 2018.

WANG, N.; ZHENG, T.; ZHANG, G.; WANG, P. A review on Fenton-like processes for organic wastewater treatment. Journal of Environmental Chemical Engineering, v. 4, n. 1, p. 762-787, 2016. 
WIEGAND, H. L.; ORTHS, C. T.; KERPEN, K.; LUTZE, H. V.; SCHMIDT, T. C. Investigation of the Iron-Peroxo Complex in the Fenton Reaction: Kinetic Indication, Decay Kinetics, and Hydroxyl Radical Yields. Environmental Science \& Technology, v. 51, n. 24, p. 1432114329, 2017.

XIONG, Q.; BAI, Q.; LI, C.; HE, Y.; SHEN, Y.; UYAMA, H. A cellulose acetate/Amygdalus pedunculata shell-derived activated carbon composite monolith for phenol adsorption. RSC Advances, v. 8, n. 14, p. 7599-7605, 2018.

YARGIC, A. S.; OZBAY, N. Fenton and Photo-Fenton Degradation of Reaktoset Brilliant Orange/P-2R and Telon Turquoise/M-GGL Dyes: Effect of Operating Parameters and Kinetic Study. International Journal of Advanced Research in Chemical Science, v. 3, n. 2, p. 38-45, 2016.

ZHANG, C.; SONG, W.; ZHANG, X.; LI, R.; ZHAO, S.; FAN, C. Synthesis and evaluation of activated carbon spheres with copper modification for gaseous elemental mercury removal. Journal of Porous Materials, v. 26, n. 3, p. 693-703, 2019.

ZHOU, H.; ZHEN, W.; ZHU, Q.; WU, X.; CHANG, Z.; LI, W. Role of the surface chemistry of activated carbons in dye removal from aqueous solution. International Journal of Minerals, Metallurgy, and Materials, v. 22, n. 7, p. 770-776, 2015. 